\title{
Brief Review of Dinosaur Studies and Perspectives in Brazil*
}

\author{
ALEXANDER W. A. KELLNER ${ }^{1 * *}$ and DIOGENES A. CAMPOS ${ }^{2 * * *}$ \\ ${ }^{1}$ Departamento de Geologia e Paleontologia, Museu Nacional/UFRJ \\ Quinta da Boa Vista, s/n São Cristóvão, 20940-040 Rio de Janeiro, RJ, Brasil. \\ ${ }^{2}$ Museu de Ciências da Terra - DNPM Av. Pasteur, 404 Urca, 22290-240 Rio de Janeiro, RJ, Brasil. \\ Manuscript received on May 22, 2000; accepted for publication on June 19, 2000.
}

\begin{abstract}
Dinosaur research is developing at very high rates around the world resulting in several new discoveries that are improving our understanding of this terrestrial reptilian clade. Except for the last couple years, the studies of Brazilian dinosaurs have not followed this expansive trend, despite the high potential of several dinosaur localities. So far there are only eight described taxa, four in the last year, representing theropod, sauropod, and one possible prosauropod taxa. Except for footprints, there are no records of ornithischian dinosaurs in the country what is at least partially explainable by the lack of continuous vertebrate fossil collecting program in the country. More funding is necessary to improve the research activities in this field.
\end{abstract}

Key words: Paleontology, Dinosauria, Brazil.

\section{INTRODUCTION}

There is perhaps no other group of fossils that has such a popular appeal as dinosaurs. Since the term Dinosauria was coined and first used in 1842 by the English comparative anatomist and paleontologist Richard Owen to group three previously described taxa (Padian 1997), the studies of those animals have experienced a tremendous increase and there are now far over 1000 described species. This group of reptiles first appeared in the geological record in the Late Triassic (some 225 million years ago) and almost got extinct at the end of the Cretaceous. Only one managed to survive and presently constitute one of the most diverse clade of vertebrates: the birds (Aves). Although not universally accepted (e.g., Feduccia 1996), the theory that birds have descended

\footnotetext{
*Invited paper

**Foreign Member of the Academia Brasileira de Ciências

*** Member of the Academia Brasileira de Ciências

Correspondence to: Alexander Wilhelm Armin Kellner

E-mail: kellner@acd.ufrj.br
}

from a group of theropod dinosaurs is gaining gradually more support (e.g., Witmer 1991).

Despite being studied for almost 160 years, it seems that research on dinosaurs (excluding postMesozoic birds) is higher than ever. More expeditions are unearthing new specimens from different parts of the world than ever and the techniques that are being employed to study those creatures are getting increasingly more sophisticated (e.g., CTscans, scanning electron microscope, DNA analyses). Moreover, popular interest continues to grow, particularly after the production of films like the "Jurassic Park" series and TV documentaries such as the latest "Walking with Dinosaurs" (BBC - London). All this results in a tremendous and continuous increase of the field.

However, this "expansion" is not equal around the globe. While paleontologists in North America, Europe, Argentina, and China (among others) are studying these fossils and are producing more publi- 
cations than ever before, in some countries dinosaur studies tend to continue comparatively slow. Among those is Brazil, a country that has a continental size with several Mesozoic outcrops and therefore a high potential for new findings.

The present article offers a brief review of the dinosaur studies, focussing on the present knowledge of Brazilian dinosaurs, and discusses the perspectives of the growth of the field in the country.

\section{EARLY DISCOVERIES}

The knowledge of dragons and large animals in human culture is very old. Although intuitively those accounts tend to be referred to dinosaurian remains, most of them have been reported from caves and are associated with elements of big mammals. Even nowadays it is very common that the laymen mistakes "huge" Pleistocene bones for dinosaurs.

Also in Brazil there are such reports. The most unusual one can be found in the sandstones of the Antenor Navarro Formation (Paraíba), where symbols were carved inside the rocks around dinosaur footprints. Those marks are attributed to Amerindians that most certainly noted these footprints, although likely not having the notion what they were in reality (Leonardi 1984, pers. comm. 1985).

The first dinosaur bone ever to be figured is the distal end of a femur found in England, first pictured by Robert Plot in 1677 and later by Richard Brookes in 1763 (Sarjeant 1997). Brookes regarded those remains as belonging to a giant human, using as caption of this figure the terminology scrotum humanum (Fig. 1). Still in the seventieth century a few more specimens were discovered in England, France, and United States, although their true nature was not understood at that time. The first dinosaur to be named was the lower jaw of the theropod Megalosaurus (named by James Parkinson in 1822) followed by the ornithischian dinosaurs Iguanodon (Fig. 2) and Hylaeosaurus (among a few others) named by Mantell, respectively in 1824 and 1833 (Sarjeant 1997). It was to classify those taxa that Richard Owen proposed the name Dinosauria - from the Greek mean- ing "fearfully" or "terrible great lizards" - in 1842 (and not in 1841, as generally thought - see Padian 1997). From there one several more were discovered, particularly in Europe, North America, and Asia, showing the worldwide distribution of this group of fossil vertebrates.

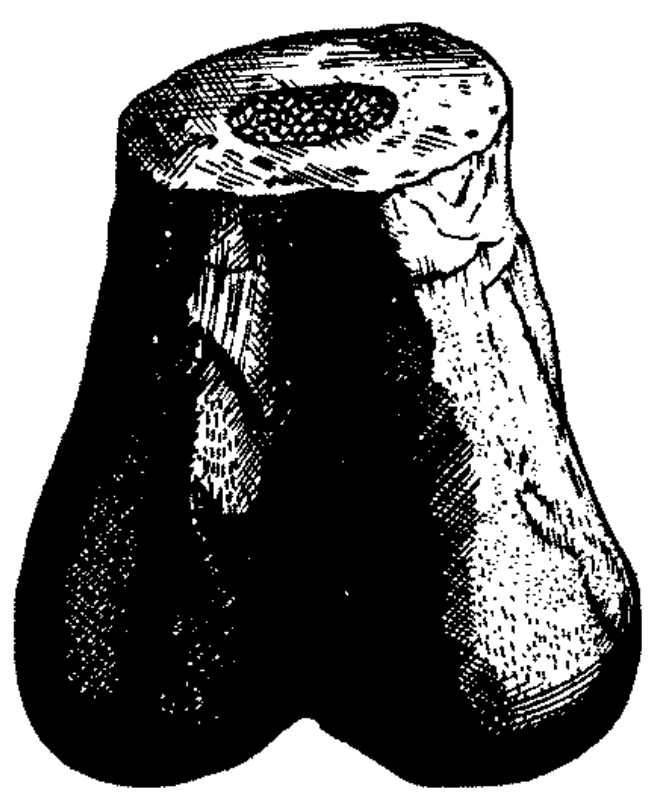

Fig. 1 - The earliest known illustration of a dinosaur bone first figured by Robert Plot in 1677 and later by Richard Brookes in 1763 (after Sarjeant 1997).

In Brazil, the first supposed dinosaur material to be mentioned in the literature was a dorsal vertebrae attributed to Megalosauridae by Allport (1860), but presently regarded as belonging to a crocodilian (Campos \& Kellner 1991). Later, in 1883, some incomplete skeletons were mentioned from Morro do Cambambe and northeastern of Cuiabá, Mato Grosso (Price 1961), whose whereabouts are unknown.

In São Paulo, the first specimen reported was one tooth from the Cretaceous outcrops of the Bauru Group in São José do Rio Preto. This and other incomplete bones (now lost) were referred to the prosauropod Thecodontosaurus (Woodward 1910, 


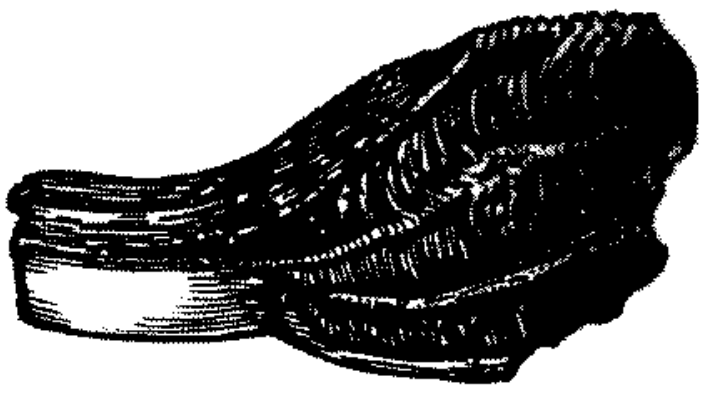

Fig. 2 - One of the fossil teeth of Iguanodon from the Wealden strata (Early Cretaceous) of England that were studied by Gideon Mantell (after Sarjeant 1997).

Ihering 1911), but, taken into account the age of the strata, most likely belong to theropod and sauropod dinosaurs. In the southern part of the country, Huene (1942) described Spondylosoma absconditum based on some postcranial remains (fragmentary limb elements and vertebrae), that he regarded as an indeterminate saurischian dinosaur. Although some authors have listed this taxon within Prosauropoda (e.g., Romer 1956, Colbert 1970), its dinosaurian nature has to be yet established (Sues 1990).

Perhaps the paleontologist that most contributed in the discovery of dinosaur remains in Brazil was Llewellyn Ivor Price (1905-1980). He has organized and participated in several expeditions in the country that resulted in a large dinosaur collection presently housed at the Museu de Ciências da Terra of the Departamento Nacional da Produção Mineral (DNPM, Rio de Janeiro). Price was organizing an extensive monograph on this material, including several illustrations (e.g., Fig. 3), but passed away before having the opportunity to finish this work.

The first uncontroversial Brazilian dinosaur named is Staurikosaurus pricei, from the Santa Maria Formation (Colbert 1970). This very primitive theropod is still known from only one incomplete skeleton, although recently more dinosaur material was unearthed from the Santa Maria Formation (Azevedo et al. 1998, Bonaparte et al. 1999, and

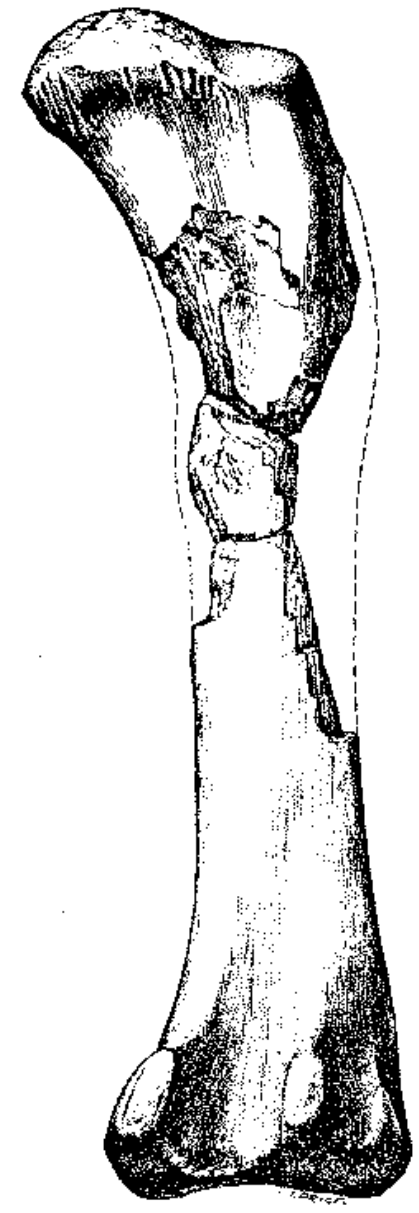

Fig. 3 - One sauropod femur discovered by Llewellyn Ivor Price in Late Cretaceous strata of the locality Mangabeira, Minas Gerais. Unpublished original drawing of Price.

Langer et al. 1999). From there on, very few studies were published regarding the dinosaur fauna of the country.

\section{DEFINITION AND PHYLOGENETIC POSITION OF DINOSAURIA}

Although Owen has regarded Dinosauria as a natural group, this was questioned several times in the past. Among those with different views was Seeley (1887, 1888) that, based on the pelvis, recognized two distinct groups: Saurischia and Ornithischia. The saurischian dinosaurs have a pelvis that is very 
similar to all remaining reptiles, with the pubis directed forward while in the ornithischian dinosaurs, the pubis is directed backwards, parallel to the ischium (Fig. 4). Seeley used this information to dismiss dinosaur monophyly, an approach followed by most paleontologists, including Romer (1956), who essentially used the term dinosaur in a popular sense. However, Seeley's proposal actually recognized two different dinosaur groups and therefore, based on modern view of systematics does not provide any evidence against dinosaur being regarded as a monophyletic group.

Only in the seventies the monophyly of Dinosauria gained more support. Bakker and Galton (1974) pointed out several morphological features present in dinosaurs and absent in other archosaurs, suggesting that they indeed form a natural group. The debate went on for some more years, with a few authors (e.g., Thulborn 1975, Charig 1976, Chatterjee, 1982) questioning this conclusion. The employment of cladistic methodology in dinosaur systematics (e.g., Gauthier 1986), however, seems to have settled this question and nowadays almost all researchers regard Dinosauria (including birds) as a monophyletic group.

In terms of definition, Dinosauria Owen 1842 is formed by the most recent common ancestor of birds and Triceratops and all its descendants (Padian \& May 1993). Therefore this group includes all ornithischian and saurischian (+ Aves) species. There are presently 17 apomorphic characters that diagnose Dinosauria, among which the presence of at least three sacral vertebrae, perforated acetabulum, and the development of brevis shelf on the lateroventral portion of the ilium (see Novas 1996, for a complete list).

Contrary to the dinosaurian monophyly, the phylogenetic position of this group within reptiles was not object of substantial disagreement. They are since long time regarded as part of the Archosauria, although the relationships within this group were not clearly understood (e.g., Romer 1956). Based on cladistic analyses of archosaurs, the Dinosauria, along with some other taxa (e.g., Lagosuchus, Lagerpeton) are presently considered the sister group of Pterosauria + Scleromochlus, forming the clade named Ornithodira (Gauthier 1986, Sereno 1991; Fig. 5).

\section{THE DAWN OF THE DINOSAURS}

Dinosaur origin is perhaps one of the most intriguing topics regarding Vertebrate Paleontology. The reason those reptiles rise in the Middle to Late Triassic and became the dominant terrestrial group of vertebrates from the end of the Triassic to the end of the Cretaceous is still a matter of debate.

Although this question is certainly far from being adequately answered, some important discoveries of basal ornithodirans (including primitive dinosaurs), particularly from terrestrial Triassic strata of Argentina (Ischichuca and Ischigualasto formations), have shed some light on the early stages that resulted in the evolution of dinosaurs.

Presently, the most immediate dinosaur forerunners are Lagosuchus, Lagerpeton, Marasuchus (Fig. 6), Pseudolagosuchus, and Lewisuchus, all from the Ischichuca Formation, whose age is thought to be middle Triassic (Bonaparte 1982). Lagosuchus comprises two species, L. talampayensis and "L." lilloensis, both based on incomplete specimens (Romer 1971, 1972). Sereno and Arcucci (1994) considered the first one nomen dubium and renamed the second (Marasuchus lilloensis). Pseudolagosuchus and Lewisuchus are not very well known and might represent the same taxon (Arcucci 1997). Bonaparte (1995) also pointed out that Marasuchus lilloensis might be based on a juvenile specimen of Pseudolagosuchus major Arcucci 1987. Despite the fact that all the above mentioned taxa being based on incomplete or not well preserved specimens, particularly regarding the skull, they comprise the best and only known evidence of "protodinosaurs".

The terrestrial Triassic of Argentina has also yielded some of the most primitive dinosaurs: the theropods Eoraptor and Herrerasaurus (Novas 

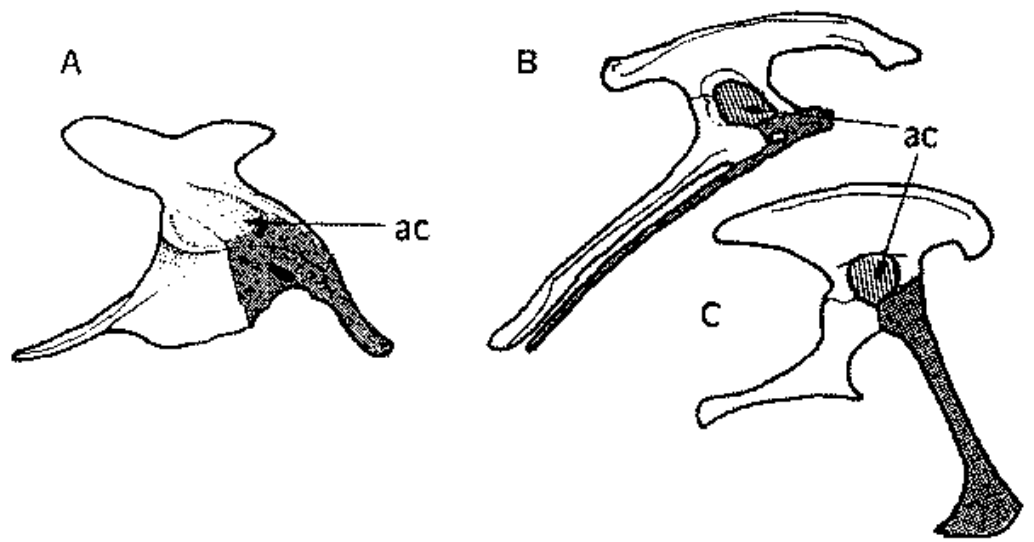

Fig. 4 - Schematic illustration of reptilian pelves in right lateral view (not to scale): A - basal archosaur; B - Ornithischia; C - Saurischia. Note that the acetabulum (ac) is closed in basal archosaurs and open in dinosaurs. The pubis (darker) is directed forward in Saurischia (a plesiomorphic condition also present in basal archosaurs), while directed backward in Ornithischia (a derived condition).

1993, Sereno 1993, Sereno \& Novas 1993); and the ornithischian Pisanosaurus (Casamiquela 1967, Weishampel \& Witmer 1990). All those taxa came from the younger Ischigualasto Formation (early Late Triassic - Bonaparte 1982, Rogers et al. 1993). Other primitive dinosaurs are Staurikosaurus (Colbert 1970) from the Late Triassic Santa Maria Formation (Barberena et al. 1985), Alwalkeria (Chatterjee 1987, Chatterjee \& Creisler 1994), and Chindesaurus from the late Carnian - early Norian strata of the Chinle Formation (Murry \& Long 1989, Novas 1997). From those, the best-preserved ones are Eoraptor (not completely studied yet) and Herrerasaurus, providing important information about the first dinosaurs to walk on the planet.

Those occurrences started to provide a faint picture of the morphological modification that basal ornithodirans acquired leading to the first dinosaurs. The most recent analysis of those steps was provided by Novas (1996), who concluded that Pseudolagosuchus is the closest related taxon to Dinosauria, followed stepwise by Marasuchus and Lagerpeton (Fig. 7). This study confirmed that bipedality was developed very early in basal ornithodirans (Gauthier 1986) that progressively changed their hind limb morphology and supposedly improved their locomotor capabilities. At the dinosaurian level, however, the main changes are observed in the pelvis, such as the development of a brevis shelf on the ilium, the perforated acetabulum, ilium developing a slender shaft and ventral "keel-like expansion", and the addition of one dorsal vertebra (dorsosacral) to the sacrum (Novas 1996). This analysis also showed that the forelimbs stayed more conservative and did not modify as fast in the pre-dinosaurian ornithodirans.

Despite these results, it should be noted that we are still missing a lot of information regarding the early evolution of dinosaurs. Based on the presence of Pseudolagosuchus (the sister group of Dinosauria) in the early Middle Triassic, primitive dinosaur must have been present during this time, although none was reported (or recognized) so far. During the early Carnian, dinosaurs were already adapted to herbivory (with Pisanosaurus) and carnivory (Eoraptor, Herrerasaurus, Staurikosaurus), 


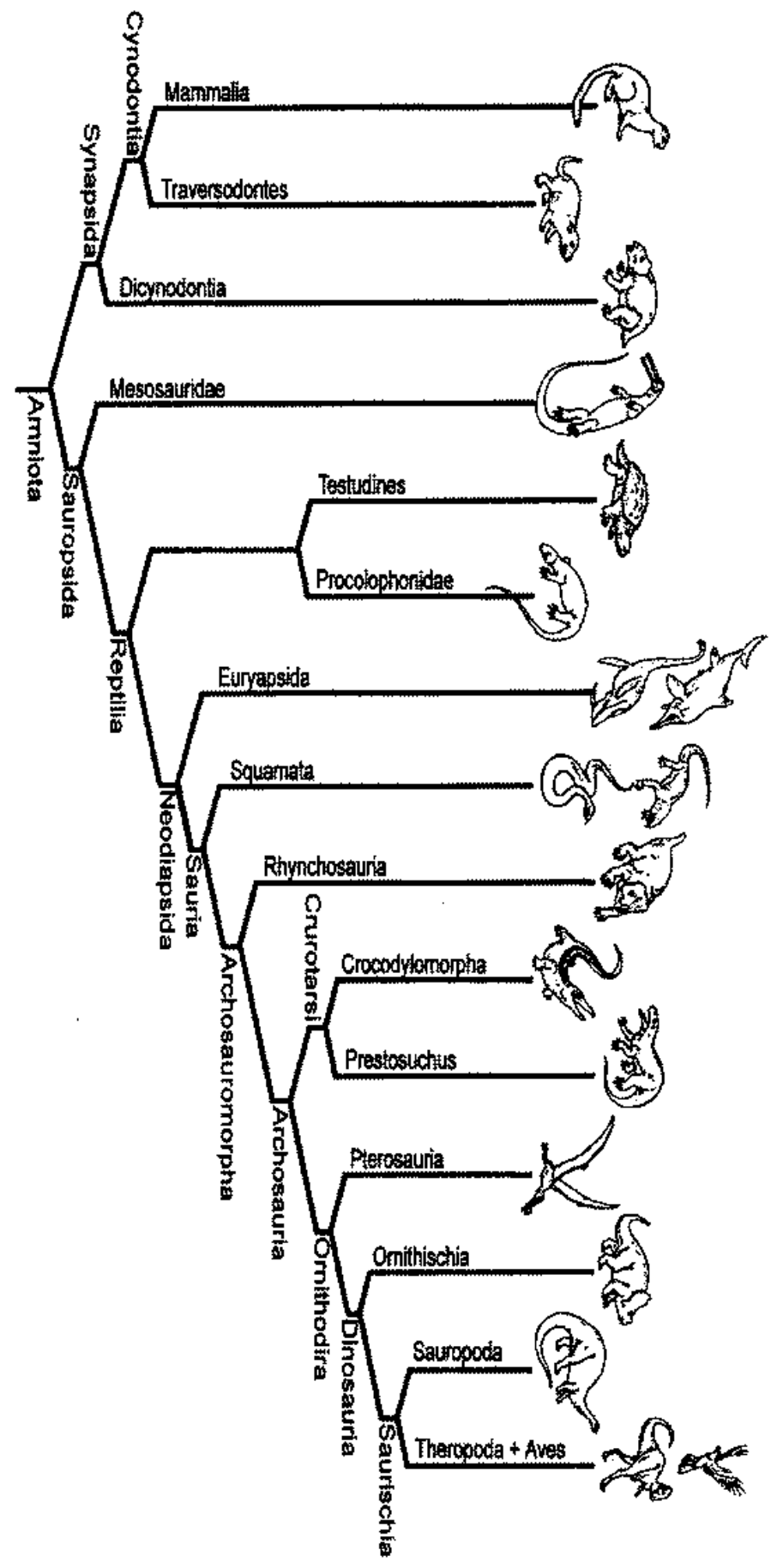

Fig. 5 - Cladogram indicating the relationships of the main groups of Amniota, with emphasis on Reptilia. Note that dinosaurs have a sister group relation with Pterosauria, both forming the Ornithodira (from Kellner et al. 1999b). 


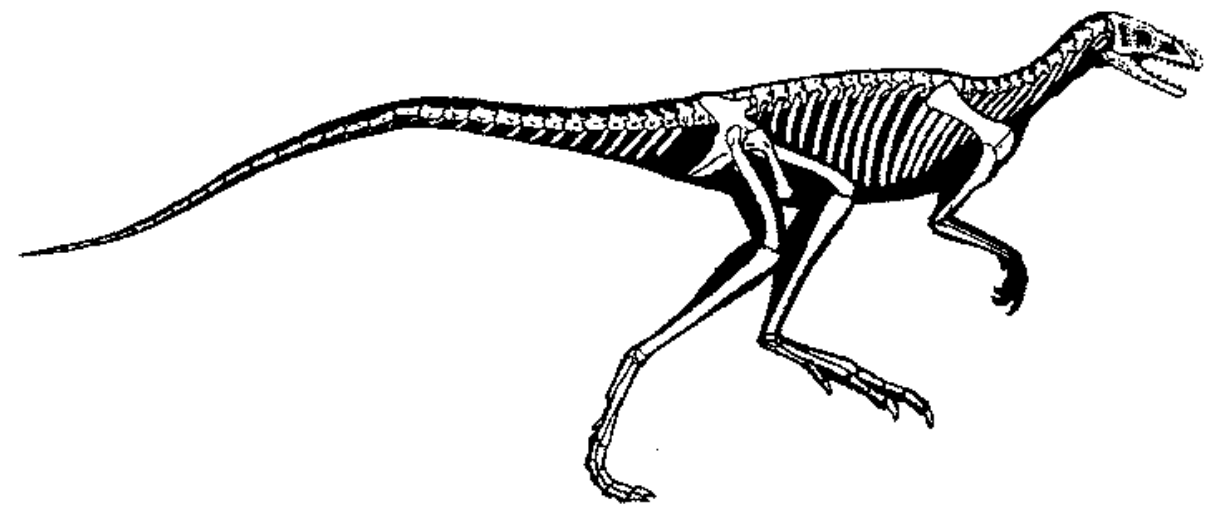

Fig. 6 - Schematic reconstruction of the skeleton of Marasuchus, a $1 \mathrm{~m}$ long basal pre-dinosaur ornithodirans (based on Sereno \& Arcucci 1994).

contributing to the notion that those adaptations must have started much earlier. But the actual dominance of dinosaurs came much later (15 million years or more), at the end of the Triassic, when the plant-eating prosauropods and the coelophysoid ceratosaurs predators roomed Pangea (Sereno 1999). Until this time, the most abundant herbivorous were the synapsid dicynodonts and the primitive archosauromorphs called rhynchosaurs, with crurotarsians like Prestosuchus and Rauisuchus at the top trophic level. How and why dinosaurs came to dominate the terrestrial fauna is still wide open to discussions.

\section{DINOSAUR DIVERSITY}

As pointed out before, Seeley $(1887,1888)$ proposed the primary division of dinosaurs. Based on the pelvic structure, this author erected the Saurischia and the Ornithischia as two distinct reptilian orders. Notwithstanding Seeley's opposition to dinosaur monophyly, the recognition of this first dichotomy in dinosaur systematics is widely accepted. Therefore, per definition, all dinosaurs have to be a member of one or the other.

Nowadays there are several studies of saurischian and ornithischian in-group relationship and several hypotheses have been presented (e.g., Gau- thier 1986, papers in Weishampel et al. 1990 and Currie \& Padian 1997, Sereno 1999). In the next paragraphs we will briefly discuss the major dinosaur clades within these two groups (Fig. 8), emphasizing those represented in Brazil.

\section{ORNITHISCHIAN DINOSAURS}

Among the main features that diagnose ornithischians are the presence of a predentary bone, tip of the premaxilla lacking teeth with a rough surface (probably covered by a horny bill), lateral depression (or cheek) on jaws, five or more sacral vertebrae, and posteroventrally directed pubis. The presence of leaf-shaped teeth, with denticles on the carena is also a feature commonly listed as diagnostic of this taxon (e.g., Sereno 1999) but is also present in prosauropods, and must have been acquired by those taxa independently. All are regarded as herbivorous and comprise bipedal and quadrupedal forms. Although their distribution is worldwide, no representative of this dinosaur clade was found in Brazil so far, except for possibly some footprints (Price 1961, Leonardi 1979, 1994).

Primitive ornithischian dinosaurs are very rare. So far, the most primitive members of this group are Pisanosaurus (Ischigualasto Formation, early Late Triassic, Argentina), Technosaurus (Dockum 


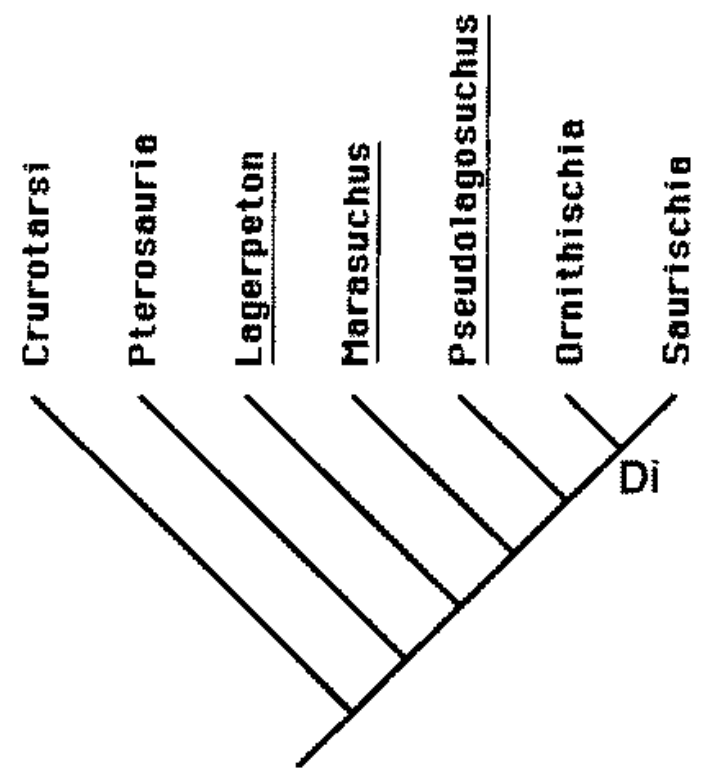

Fig. 7 - Cladogram indicating the relationships of basal ornithodirans (based on Novas 1996). Abbreviation: Di - Dinosauria.

Formation, early Late Triassic, Texas), and Lesothosaurus (Upper Elliot Formation, early Lower Jurassic, Lesotho). Except Lesothosaurus, all are based on very incomplete material (Weishampel \& Witmer 1990). Those animals are not very large (1 to $2 \mathrm{~m}$ ) and were probably herbivorous. Based on their limbs and the comparatively light aspect of their skeletons, these early ornithischians are interpreted to have been relatively active, cursorial bipeds (Thulborn 1982).

The remaining members of the Ornithischia are classified in the Genasauria, composed of the Thyreophora, Marginocephalia, and Ornithopoda (Fig. 8). Thyreophorans are characterized by the presence of a body armor and hoof-shaped unguals. The most basal member of this group is Scutellosaurus from the Kayenta Formation (Hattengian, Lower Jurassic - Arizona), and is regarded as a bipedal animal. Most of thyreophorans, however, are quadrupedal, and comprise some of the most popular dinosaurs such as stegosaurs and ankylosaurs. Stegosaurs tend to have a subrectangular

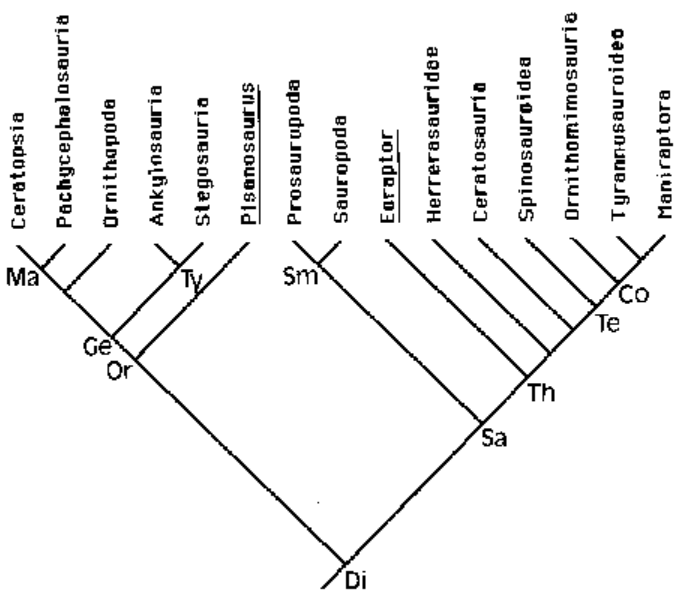

Fig. 8 - Cladogram indicating the relationships of the main dinosaur groups (based on Sereno 1999). Abbreviations: Co - Coelurosauria; Di - Dinosauria; Ge - Genasauria; Ma Marginocephalia; Or - Ornithischia; Sa - Saurischia; Sm Sauropodomorpha; Te - Tetanurae; Th - Theropoda; Ty Thyreophora.

skull and developed bony plates on the dorsal midline of their bodies. Ankylosaurs acquired a complete body dermal armor and several bones in their skull overgrew some of the skull openings, giving those animals a very bizarre cranial configuration.

The Marginocephalia, characterized by the presence of a shelf on the posterior part of the skull (formed by parietal and squamosal), is further subdivided in Pachycephalosauria and Ceratopsia, the latter comprising the Protoceratopsidae and the Ceratopsidae. All pachycephalosaurs are bipedal dinosaurs and some have thickened the frontal and parietal bones, giving their skulls a doomed shape appearance. Ceratopsians include Protoceratops from the Cretaceous of Mongolia, known by some hundreds of specimens, and Triceratops from the Cretaceous of North America, which has developed large horns on the skull.

The Ornithopoda were among the most successful ornithischian dinosaurs presently known comprising some of the best adapted forms for herbivory. They all have displaced the jaw articula- 
tion, which is ventrally offset relative to the maxillary tooth row. This dinosaur clade includes the Iguanodontia (e.g., Camptosaurus, Iguanodon) and Hadrosauroidea. Hadrosaurs are among the best studied dinosaurs and are quite common in Upper Cretaceous strata. Those dinosaurs have developed dental batteries composed of closely packed tooth that made them exceptionally adapted for processing plant material. Most species were found in North America, but they are also represented in Europe, Asia, and South America. In the latter continent they were unearthed in the Bajo Barreal Formation (? Maastrichtian) and Los Alamitos Formation (late Campanian - early Maastrichtian), both in Rio Negro, Argentina (Brett-Surman 1979, Bonaparte et al. 1984).

As pointed out before, no ornithischian dinosaur clade is represented in Brazil so far. In Argentina, other than hadrosaurs, some limited bones of other ornithischian groups have been found recently, all in Late Cretaceous strata. Among those is a dorsal cervical vertebra referred to Stegosauria (Bonaparte 1996), Gasparinisaura, a basal iguanodontian known by partial skeletons including cranial material (Coria \& Salgado 1996, Salgado et al. 1997), and the only South American record of ankylosaurs, composed of one femur and a few vertebrae (Salgado \& Coria 1996). Although admittedly speculative, from all ornithischian clades, hadrosaurs are the ones that have the greatest potential to be found in Brazil, particularly in the Late Cretaceous lithoestratigraphic units of the Bauru Group.

\section{SAURISCHIAN DINOSAURS}

Comprising all dinosaurs that are closer to birds than to Ornithischia, saurischian dinosaurs are diagnosed by the presence of several features in their hands and feet (Sereno 1999). It should be noted that the "lizard-like" pelvis pointed out by Seeley $(1887,1888)$ as diagnostic of this taxon is nowadays considered a plesiomorphic characteristic, present in several basal archosaurs and cannot be used to define this clade.
Saurischians are divided into two basal groups: Sauropodomorpha and Theropoda (Fig. 8). Sauropodomorphs, diagnosed by possessing a large external naris and an anterior maxillary foramen (among other features), are further divided into Prosauropoda and Sauropoda.

\section{Prosauropoda}

Prosauropods compose the first group of dinosaurs that are well distributed around the world. Their remains have been found for all in Upper Triassic strata of Morocco, South Africa, Lesotho, United States, Europe (particularly in Germany), and Argentina. Some authors have questioned if prosauropods constitute a monophyletic group (e.g, Gauthier 1986), but based on several features like the twisted first phalanx of manual digit I with an enlarged ungual (among others) suggest that they are monophyletic (Galton 1990, Sereno 1999). Based on their leaf shaped dentition with denticles on the carena, prosauropods are regarded by most authors to have been herbivorous animals.

Very recently, a partial skeleton, including the skull, was collected in the Late Triassic strata of the Caturrita Formation (Brazil), which is now under study (Azevedo et al. 1998). This specimen constitutes a new taxon (Kellner et al. 1999a) that is apparently not closely related to the Argentinean plateosaurid prosauropods Coloradisaurus and Mussaurus but closer to Melanorosauridae (Fig. 9).

\section{SAUROPODA}

The clade Sauropoda comprises some of the largest animals ever to live on land. Among their synapomorphic features are the reduced deltopectoral crest on the humerus, reduced olecranon process of the ulna, and reduced forth trochanter on the femur. Some of those changes are associated with the quadrupedal posture that all members of this clade have developed. Vulcanodon, known from incomplete postcranial elements found in Lower Jurassic strata of Zimbabwe is commonly regarded as the basal member of this clade (McIntosh 1990). 


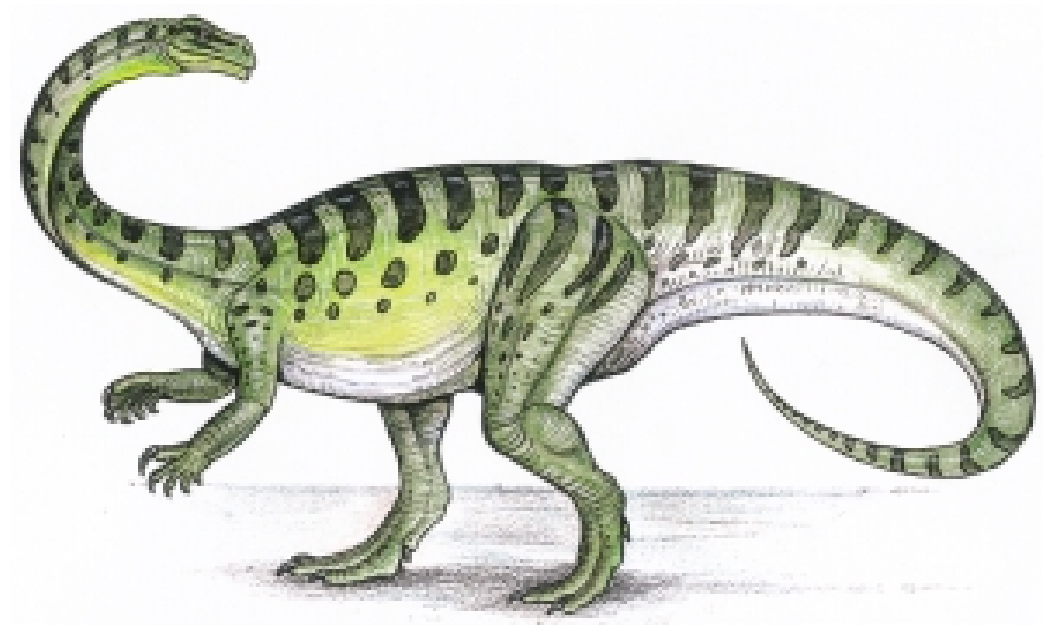

Fig. 9 - Reconstruction of a prosauropod. This group of dinosaurs was recently found in Triassic strata of Rio Grande do Sul.

Other groups of sauropods are diplodocids, camarasaurids, brachiosaurids, and titanosaurs. Of those only the latter is represented in Brazil, with two described taxa "Antarctosaurus" brasiliensis Arid and Vizotto 1971 and Gondwanatitan faustoi Kellner and Azevedo 1999. "Antarctosaurus" brasiliensis is based on three elements, all incomplete: one dorsal vertebra, one humerus, and one femur. The incomplete nature of this material difficult the establishment of a robust diagnosis of this supposedly new taxon, which can be only be regarded at this point as Titanosauria indet (Kellner \& Azevedo 1999).

The second described Brazilian titanosaurid is Gondwanatitan faustoi. This taxon is based on one partial skeleton (lacking the skull), which is the most complete Brazilian sauropod material attributable to the same individual known so far (Figs. 10-11). The anatomy of the caudal vertebrae suggests that the Brazilian taxon is closely related to the Argentinean Aeolosaurus (Kellner \& Azevedo 1999).

Besides the material mentioned above, there are some hundreds of titanosaurid sauropod bones, most found isolated or associated with each other (but rarely articulated), which constitute the most common dinosaur of Brazil. The vast majority of the remains referable to this dinosaur clade come from Cretaceous strata that comprise the Bauru Group.

Note to mention is the absence of sauropod remains at the Santana Formation (particularly the Romualdo Member) of the Araripe Basin, which has yielded some other dinosaur material (only theropods so far). This absence cannot be explained by taphonomic reasons and it is likely that sauropods constituted a very rare faunal element in the Araripe region during the Aptian-Albian.

There are also two occurrences of nontitanosaurid sauropods, one in the Itapecuru Formation (Upper Cretaceous, Maranhão) and the second at the locality known as the Laje do Coringa (Cretaceous, Maranhão). Both consist of incomplete or isolated remains (mainly vertebrae) that are still undescribed.

It should be noted that although some titanosaurid taxa have been found in Europe (e.g., Le Loeuff 1991) and North America (e.g., Gilmore 1922, McIntosh 1990), this sauropod clade is typical of the southern continents with several remains that have been unearthed in South America, particularly 


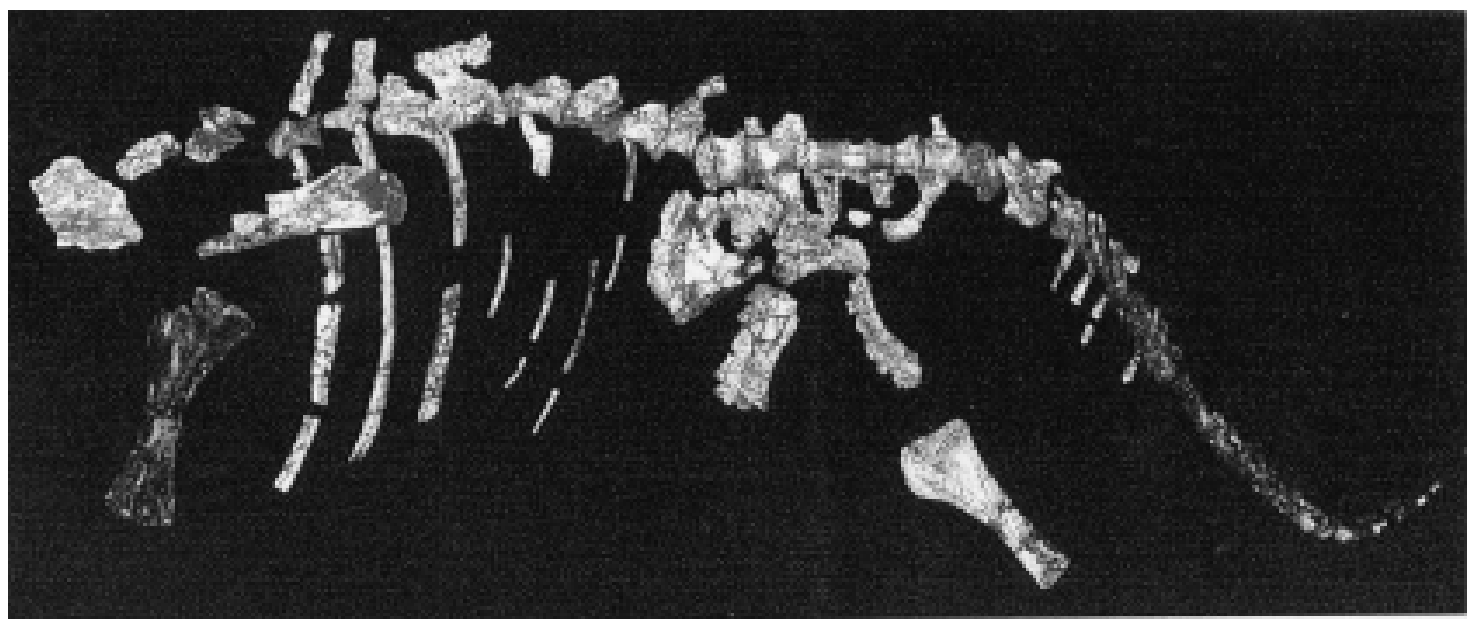

Fig. 10 - Preserved skeleton of Gondwanatitan faustoi, a titanosaurid sauropod from the Bauru Group (Upper Cretaceous) of São Paulo. This is the most complete sauropod skeleton found in Brazil so far.

Argentina (e.g., Bonaparte 1996) and Brazil. Despite the presence of some ornithischian dinosaurs in Argentina, where they form the dominant Late Cretaceous herbivores in this part of the world.

\section{THEROPODA}

The most primitive member of this clade is Eoraptor found in the Ischigualasto Formation (see chapter the Dawn of the Dinosaurs). This biped, carnivorous dinosaur was about one meter long and showed the evolutionary novelties shared by other theropods like the presence of an intramandibular joint, the presence of an ischial obturator process, and other modification in the hands. Herrerasaurids, which include the Argentinean Herrerasaurus and the Brazilian Staurikosaurus (Figs. 12-14), tend to be larger and developed modification in the tail, with the distal caudal vertebrae stiffened by the enlargement of the prezygapophyses.

All theropods more derived relative to herrerasaurids fall into two groups - Ceratosauria or Tetanurae. Although the monophyly of ceratosaurs is being questioned, Sereno (1999) pointed out some features that are unique to them such as the fused sutures of the pelvic elements and the presence of an ischial foot. Among ceratosaurs are the Abelisauridae, composed of large theropods that show several modifications in the skull, including external sculpturing. These taxa are particularly well known from Argentina, with Abelisaurus and Carnotaurus (Bonaparte 1996), the latter known by a partial skeleton making it the most complete theropod from South America. In Brazil group might be represented based on an isolated premaxilla (Bertini 1996).

The members of Tetanurae are diagnosed by a large number of synapomorphies, which include the presence of an ischial foramen and other modifications in the pelvic elements and feet. Among the more basal tetanurans are the Spinosauridae, which have rounded weakly or unserrated teeth and elongated rostrum with 7 premaxillary teeth, giving them a "crocodilian-like" appearance (for a review, see Kellner \& Campos 1996). In Brazil Irritator and Angaturama represent this clade, both from the Araripe Basin. These theropods are based on different parts of the skull, making their comparison very difficult. Nevertheless, Angaturama has apparently a higher and laterally more compressed skull than Irritator (Kellner 1996b). In any case, 


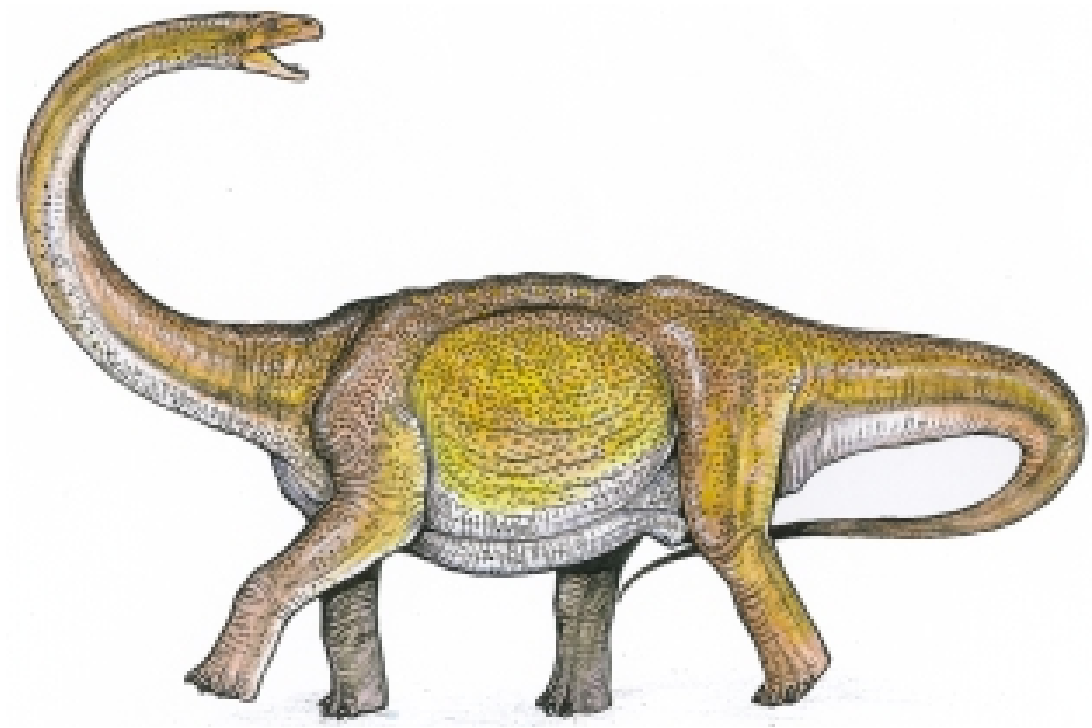

Fig. 11 - Reconstruction of Gondwanatitan faustoi, a titanosaurid sauropod. Scale bar: $1 \mathrm{~m}$.

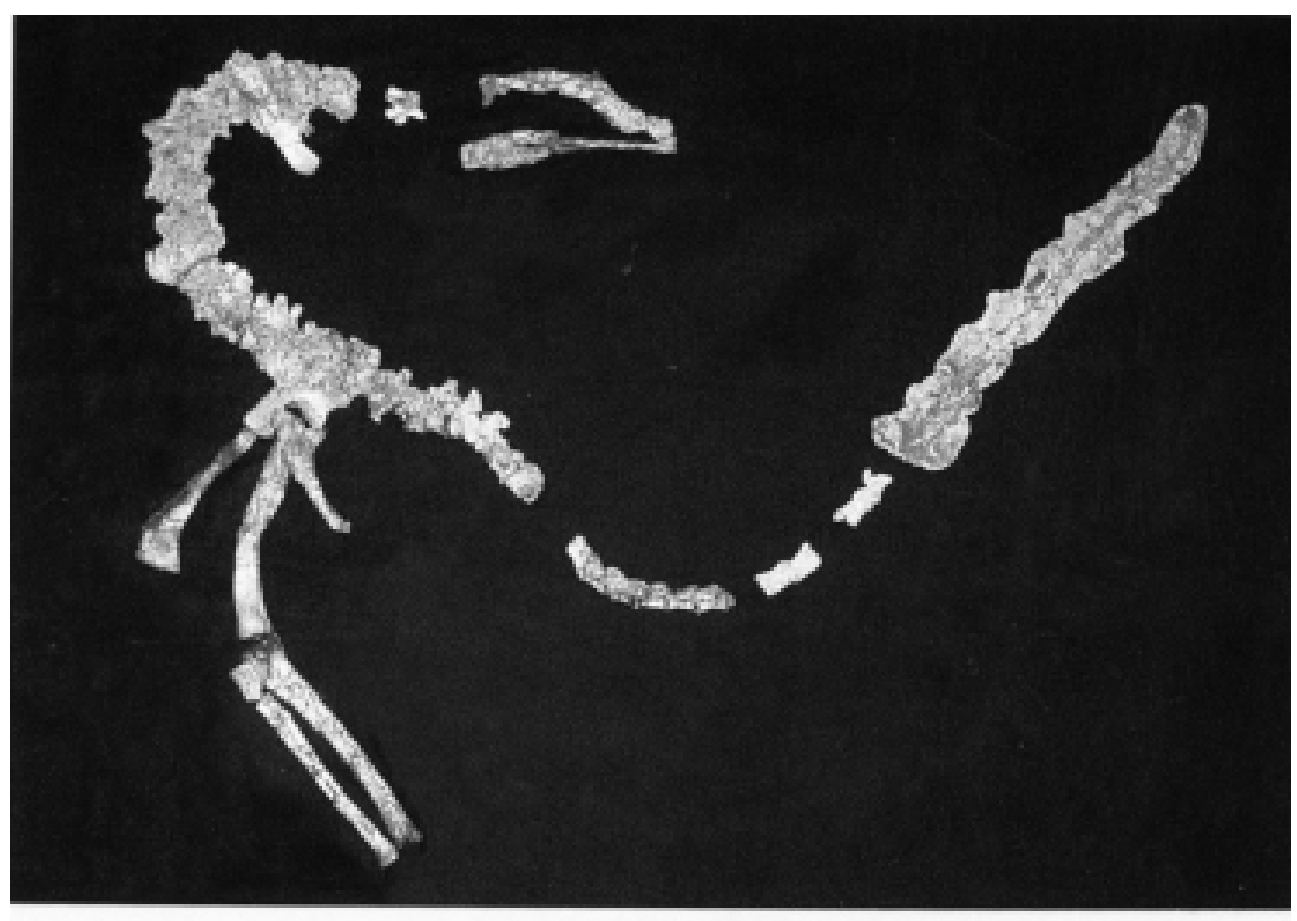

Fig. 12 - Preserved skeleton of Staurikosaurus pricei, a primitive theropod from the Santa Maria Formation (Triassic). Scale bar: $500 \mathrm{~mm}$. 


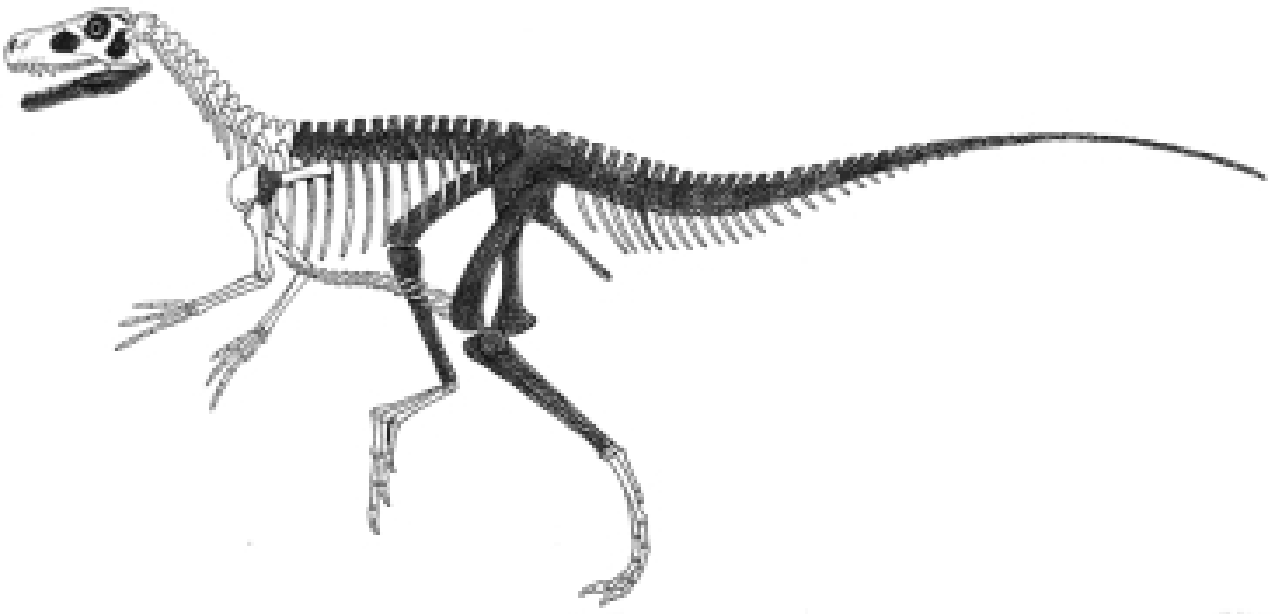

Fig. 13 - Schematic illustration of the skeleton of Staurikosaurus pricei (Theropoda), with preserved parts indicated in black.

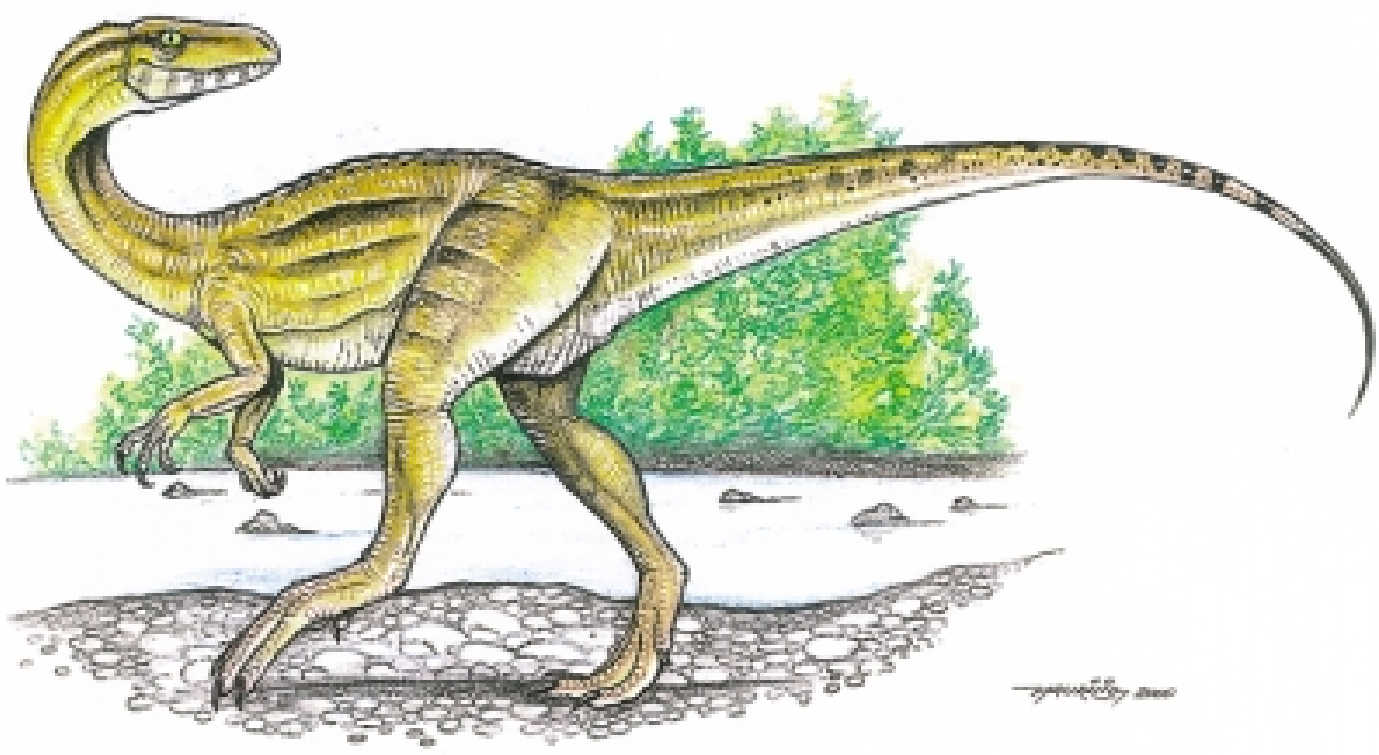

Fig. 14 - Reconstruction of Staurikosaurus pricei, a primitive theropod from the Santa Maria Formation (Triassic). 
it is likely that the Brazilian spinosaurids also had the neural spines of the dorsal vertebrae extended, forming a "sail", similar to Spinosaurus from Egypt (Stromer 1915). The extension of this sail, however, is presently unknown (Fig. 15).

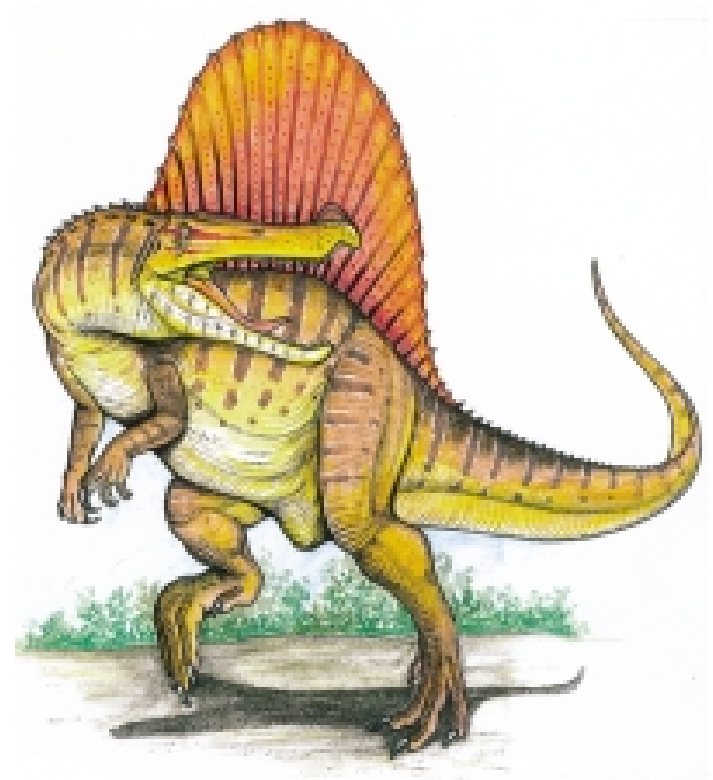

Fig. 15 - Reconstruction of the basal tetanuran Angaturama limai (Theropoda) from the Araripe Basin. The sail on the back is hypothetical and was based on Spinosaurus, with whom this taxon is closely related. Note the extension of the snout, giving this dinosaur (like other spinosaurids) a "crocodilian-like" appearance.

Another evidence of the presence of basal tetanurans in Brazil is provided by two teeth, one from the Serra da Galga locality (Fig. 16) and the second from the Morro do Cambambe. Both specimens show well developed transverse wrinkles in the enamel, particularly on the posterior part. Such structures have been found in Carcharodontosaurus from Egypt (Stromer 1931) and Giganotosaurus from Argentina (Coria \& Salgado 1995), suggesting that related taxa might have been present also in Brazil (Silva \& Kellner 1998).

Among the more derived tetanurans are the Maniraptoriformes, which include Ornithomimidae, Tyrannosauroidea, and the Maniraptora, the

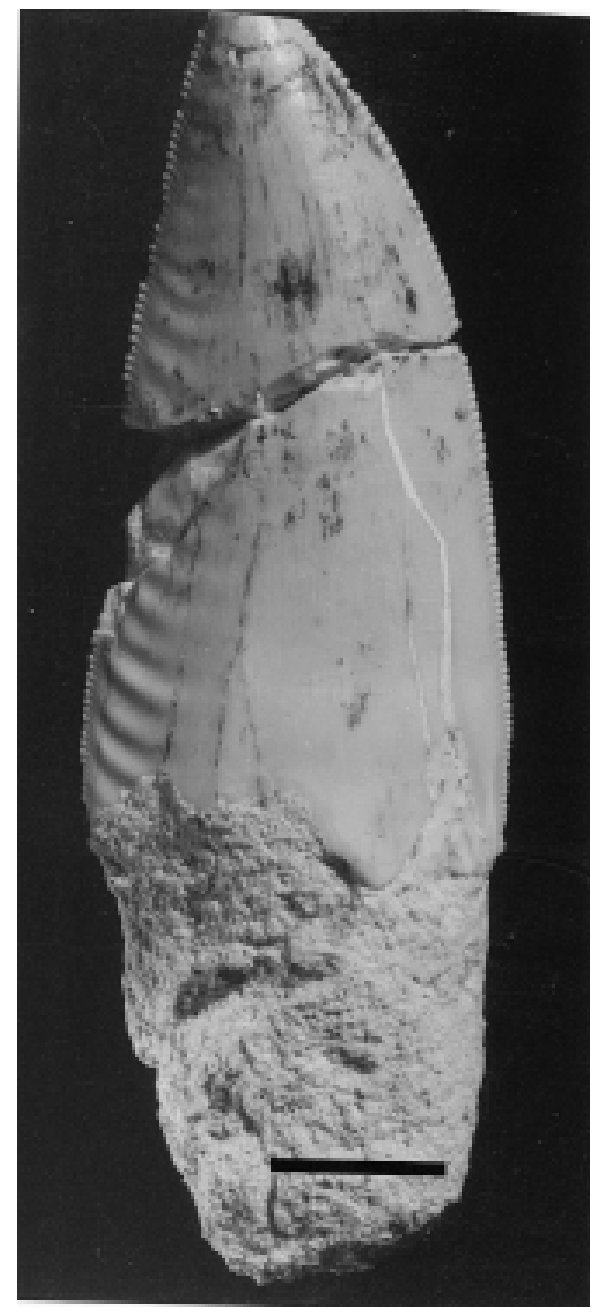

Fig. 16 - Isolated tooth found in the strata of the Late Cretaceous Bauru Group from the locality Serra da Galga, Uberaba, Minas Gerais. Note the wrinkles present particularly on the posterior margin, which are similar to basal tetanurans taxa like Giganotosaurus and Carcharodontosaurus. Scale bar: $10 \mathrm{~mm}$.

latter including the members of the Aves. The phylogenetic position of one maniraptoriform group, the Alvarezsauridae, which comprise bizarre theropods with extremely reduced forelimbs, is still controversial, with some authors placing it within Aves (Perle et al. 1994, Novas 1997) while others regard it as sister group of ornithomimids (Sereno 1999).

The only known non-avian derived tetanura 
known in Brazil so far is Santanaraptor from the Aptian-Albian Romualdo Member (Santana Formation, Araripe Basin). The specimen consists of the posterior part of a skeleton, including the ischium, caudal vertebrae, and hind limbs, associated with exceptionally well preserved soft tissue (Kellner, 1996a), and is presently regarded as a basal maniraptoriform (Kellner 1999).

\section{Aves}

The idea that birds descended from dinosaurs is quite old and was first proposed by Huxley (1870). Since that time there has been a hot debate about avian origins (see Witmer 1991 for a review), which has still not completely ended (e.g. Feduccia \& Wild 1993, Feduccia 1996). Nevertheless, the findings of several new specimens, which include "feathered dinosaurs" from Late Jurassic or Early Cretaceous strata of China (Caudipteryx and Protoarchaeopteryx) that occupy a more basal position in the Maniraptora than Archaeopteryx (Ji et al. 1998), shortens the gap between dinosaurs and birds.

The clade Aves follows the traditional use of the term "bird" and can be defined as a group formed by all the descendants of the most common ancestor of Archaeopteryx and modern birds. Most synapomorphies of Aves are found in the hand and wrist (Sereno 1999). The oldest record of this group is still $\mathrm{Ar}$ chaeopteryx discovered in the Late Jurassic Strata of Solnhofen, southern Germany. From there on this group became gradually more diversified, particularly in the Cretaceous with the Enantiornithes (Chiappe 1995).

Despite being present since the Jurassic, birds were not the most common volant vertebrates during the Mesozoic, but are outnumbered by pterosaurs in the quantity of specimens and diversity. It is also interesting to note that where pterosaur remains are common, birds are either absent or extremely rare, particularly in deposits formed near the ancient shorelines. This leaded to the hypothesis that during the Mesozoic, particularly during the Cretaceous, pterosaurs dominated these habitats and that avian faunas were more confined to terrestrial/inland regions (Kellner 1994). The fact that the Enantiornithes, perhaps the most diversified Mesozoic group of birds were recovered mainly from continental deposits (Chiappe 1995) seems to support this hypothesis.

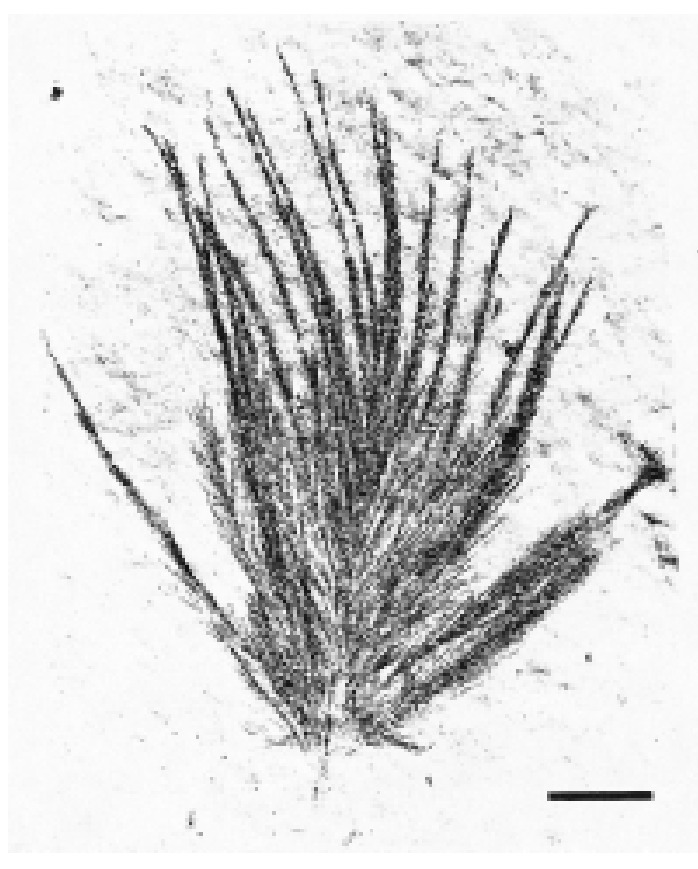

Fig. 17 - Down feather found in the Crato Member (Aptian), Santana Formation, Araripe Basin. Scale bar: $1 \mathrm{~mm}$.

No osteological materials of Brazilian Mesozoic birds were recovered so far. The only evidence of Aves from that geologic time in the country are feathers, all from the Early Cretaceous Crato Member (Aptian) of the Santana Formation, Araripe Basin (Figs 17-19). Several kinds (most undescribed) have been recovered, among which one flight feather (Martins Neto \& Kellner 1988, Kellner et al. 1991), semiplumes (Martill \& Figueira 1994), down feathers (Kellner et al. 1994), and some contour feathers, a few showing the color pattern (Martill \& Frey 1995, Kellner et al. 1999b). All have been regarded as avian, but the recent discoveries of feathered dinosaurs cast some doubts about those identifications. 
The down feathers (e.g., Fig. 17) likely belong to birds since no "true downs" have been reported in non-avian dinosaurs so far. The same is true for the only recorded flight feather, since the strong asymmetry of the vanes is more consistent with a good flying avian animal (Fig. 19). The nature of the remaining feathers is inconclusive, but, to our knowledge, semiplumes are also not known in non-avian maniraptoran dinosaurs. Contour feathers could belong to birds or non-avian theropods, although none showing the color pattern were reported in feathered non-avian dinosaurs.

In any case, the feathers found in the Crato Member indicate that early birds already possessed an effective thermoregulatory insulation cover with down feathers (Kellner et al. 1994). Those specimens further show that some animals (dinosaurs or birds) also had developed a distinct color pattern in their contour feathers, which in modern birds play several roles, particularly in behavior and communication. Likely these or similar kinds of mechanisms were present in the dinosaur evolutionary history.

\section{FOOTPRINTS AND TRACKWAYS}

Ichnofossils are defined as any record preserved in the rocks that indicates the activity of one organism. Therefore, once present, they tend to be found in comparatively large quantities. Regarding dinosaurs, the most popular ichnofossils are footprints and trackways that can be found in almost all parts of the world (Gillette \& Lockley 1989).

In Brazil dinosaur traces are present in several basins (see Leonardi 1994 for a review). One of the most recent reports were the discovery of dinosaur footprints in the more basal stratigraphical unit of the Araripe Basin, called Cariri (or Tacaratu) Formation (Carvalho et al. 1995) which was previously regarded as Paleozoic (e.g. Braun 1966). Fieldwork in the area done by one of the authors in 1999 (Kellner), however, did not identify any structure that could be referred to dinosaur footprints. Unfortunately no casts are available of those supposed dinosaur footprints. Therefore, although those strata

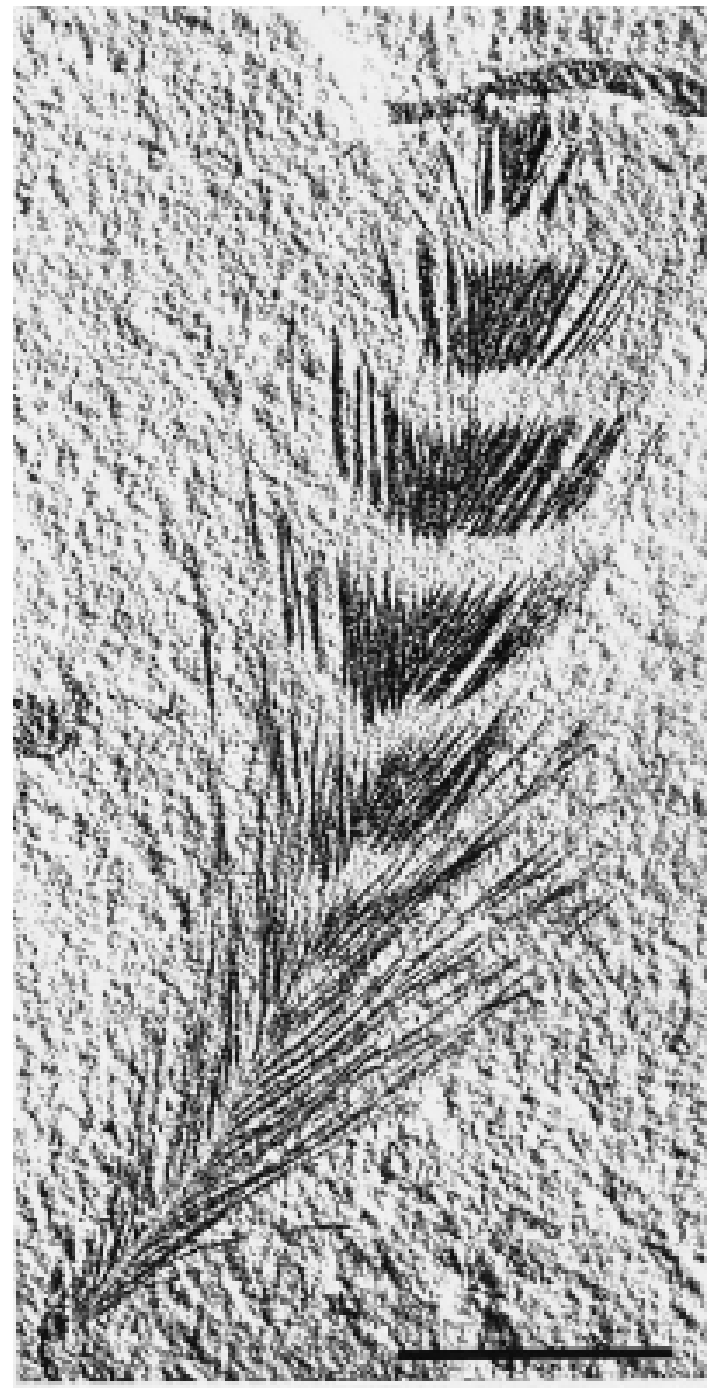

Fig. 18 - Contour feather from the Crato Member (Aptian), Santana Formation, Araripe Basin. Observe the dark and lighter bands, indicating the color pattern. Scale bar: $5 \mathrm{~mm}$.

might be indeed Cretaceous in age (Berthou 1990), there is presently no conclusive paleontological evidence for that.

Dinosaur tracks are particularly common in the Late Jurassic-Early Cretaceous strata of the Rio do Peixe Basin (Leonardi 1994). Some of those tracks are regarded as belonging to ornithischian dinosaurs (Fig. 20), a hypothesis first presented by Price (1961) and later confirmed by Leonardi (1979). The 


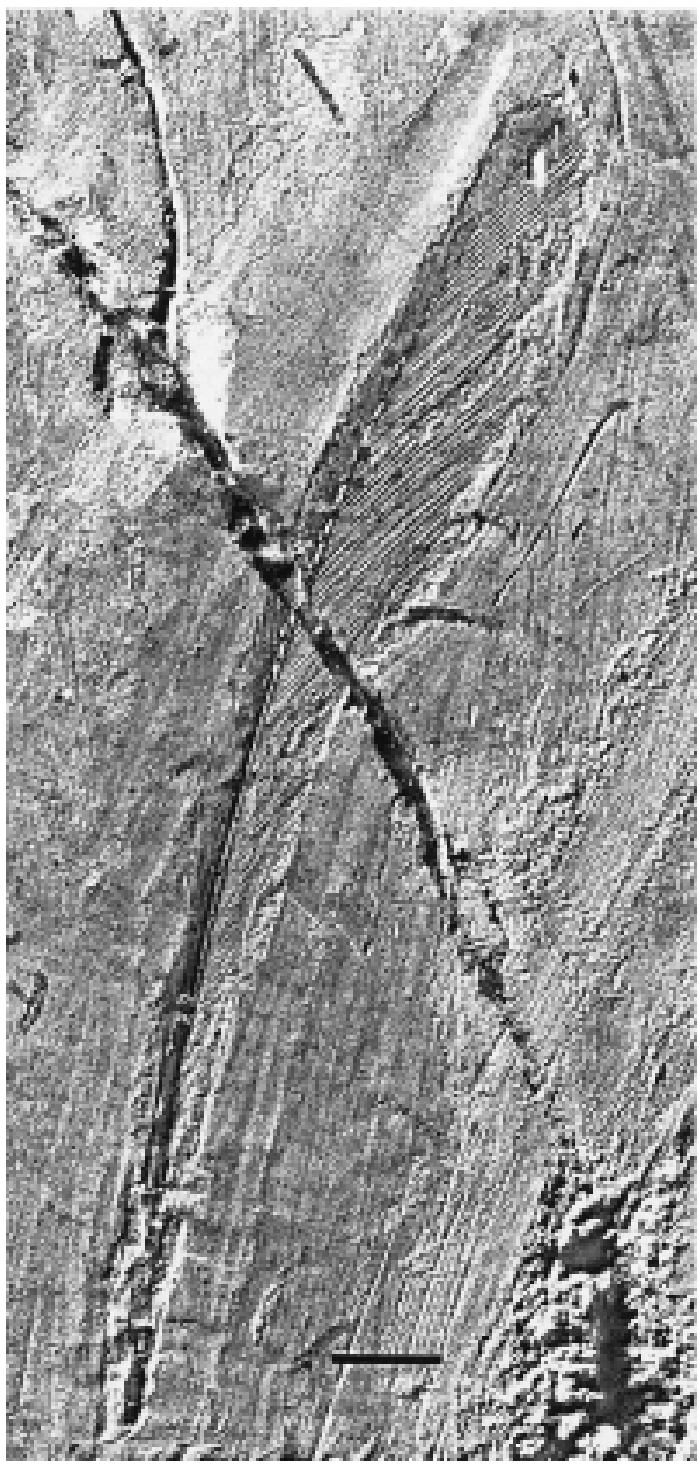

Fig. 19 - Flight feather from the Crato Member (Aptian), Santana Formation, Araripe Basin. Scale bar: $5 \mathrm{~mm}$.

identification of those tracks are not very easy and in some cases their affinities had been reinterpreted (e.g., Leonardi 1994).

Also regarded as ichnofossils but less common are dinosaur eggs. They are found in several parts of the world and their study has advanced very much in the last decades (e.g., Mikhailov et al. 1996). In Brazil there are only two published reports of such fossils. The first one consists of a rounded, comparatively large egg referred to titanosaurs, which was found in Mangabeira, north of Uberaba, Minas Gerais (Price 1951). The second consists of three elongated eggs (Fig. 21) that were initially attributed to ornithischian dinosaurs (Campos \& Bertini 1985) but thin sections of the eggshell revealed that they belong to theropods (Kellner et al. 1998).

\section{DINOSAUR LOCALITIES IN BRAZIL}

In this chapter we summarize the information regarding dinosaur localities from Brazil (Fig. 22), updating and extending the list presented by Campos and Kellner (1991). We do not include in this list the localities with ichnofossils (except eggs) that were already recently listed and discussed by Leonardi (1994). The information is presented here according to the geological age, geographic location, and lithoestratigraphic unit. All published and some unpublished records are listed and, where pertinent, commented.

\section{Late Triassic}

State of Rio Grande do Sul

\section{Santa Maria Formation}

1. Alemoa, Santa Maria (Colbert 1970).

Theropoda

\section{Staurikosaurus pricei Colbert 1970}

The specimen consists of an incomplete skeleton formed by lower jaws, cervical, dorsal, sacral and caudal vertebrae, part of scapula and humerus, pelvis, femura, tibiae, and fibulae, collected by Llewellyn Ivor Price in 1937.

2. Chiniquá, western of Santa Maria (Huene 1942).

Dinosauria incertae sedis

\section{Spondylosoma absconditum Huene 1942}

The specimen consists of the distal part of left scapula, proximal end of right humerus, distal part of left femur, fragment of left tibia, and eight vertebrae. Huene (1942) has regarded it as a saurischian, 


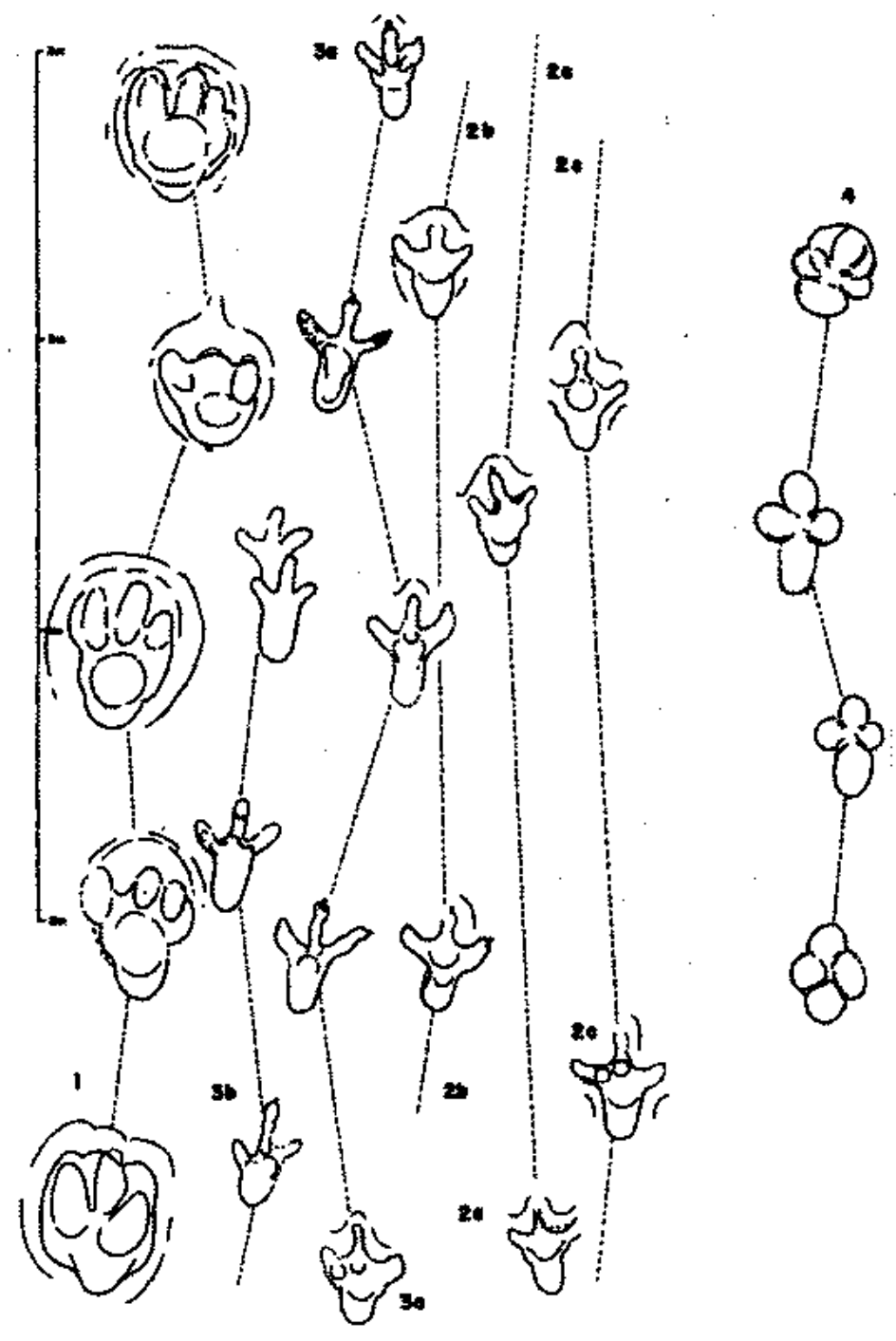

Fig. 20 - Trackways from the locality Passagem das Pedras, Sousa, Paraíba. Those tracks were found in the strata of the Sousa Formation: 1 - Sousaichnium pricei Leonardi 1979, attributed to Iguanodontidae; 2 and 3 - Moraesichnium barberenae Leonardi 1979, attributed to a theropod; 4 - Staurichnium diogenis Leonardi 1979, attributed to Iguanodontidae (from Leonardi 1994). Trackways 1 and 4 are regarded as evidences of the presence of Ornithischian dinosaurs in Brazil (Leonardi 1979, 1994). 


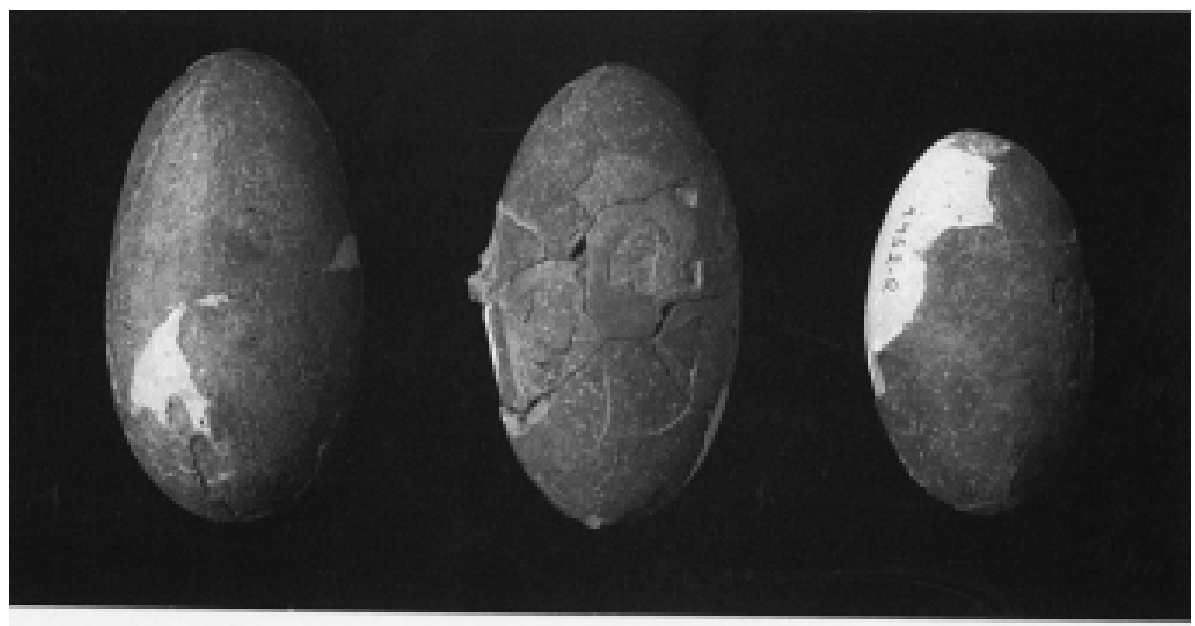

Fig. 21 - Three theropod dinosaur eggs, from the Late Cretaceous strata of the Uberaba Formation, Minas Gerais.

but its dinosaurian nature has been questioned (Sues 1990). Colbert (1970) mentioned that two laterally compressed serrated teeth might be associated with this specimen.

3. Wald Sanga on the outskirts of the town Santa Maria (Langer et al. 1999).

Sauropodomorpha

Saturnalia tupiniquim Langer, Abdala, Richter and Benton 1999

Three incomplete skeletons (lacking the skull) that are regarded as belonging to a primitive sauropodomorph. The close relationships of this taxon within this clade, however, are yet to be established.

\section{Caturrita Formation}

4. Outcrop on the Santa Maria - Candelária Highway at $7.5 \mathrm{~km}$ from Candelária.

Theropoda incertae sedis

Guaibasaurus candelarai Bonaparte et al. 1999

This species is based in two skeletal materials, both lacking the skull. One consists essentially of an incomplete skeleton with dorsal and caudal vertebrae, incomplete pelvis, and parts of the hind limbs; the second is an incomplete hind limb. Due to the anatomical characteristics of the foot, a prosauropod nature of Guaibasaurus cannot be disregarded at this point.

5. Água Negra, Santa Maria (Azevedo et al. 1998).

Prosauropoda

Gen \& sp. nov.

The material consists of the most complete Triassic dinosaur collected from Brazil so far (including an incomplete skull) and is being presently prepared and studied (Azevedo et al. 1998, Kellner et al. 1999a).

\section{Early Cretaceous}

State of Ceará

\section{Crato Member, Santana Formation}

6. Nova Olinda - Santana do Cariri (Martins Neto \& Kellner 1988).

Avian flight feathers (Martins Neto \& Kellner 1988, Kellner et al. 1991, Fig 19). 


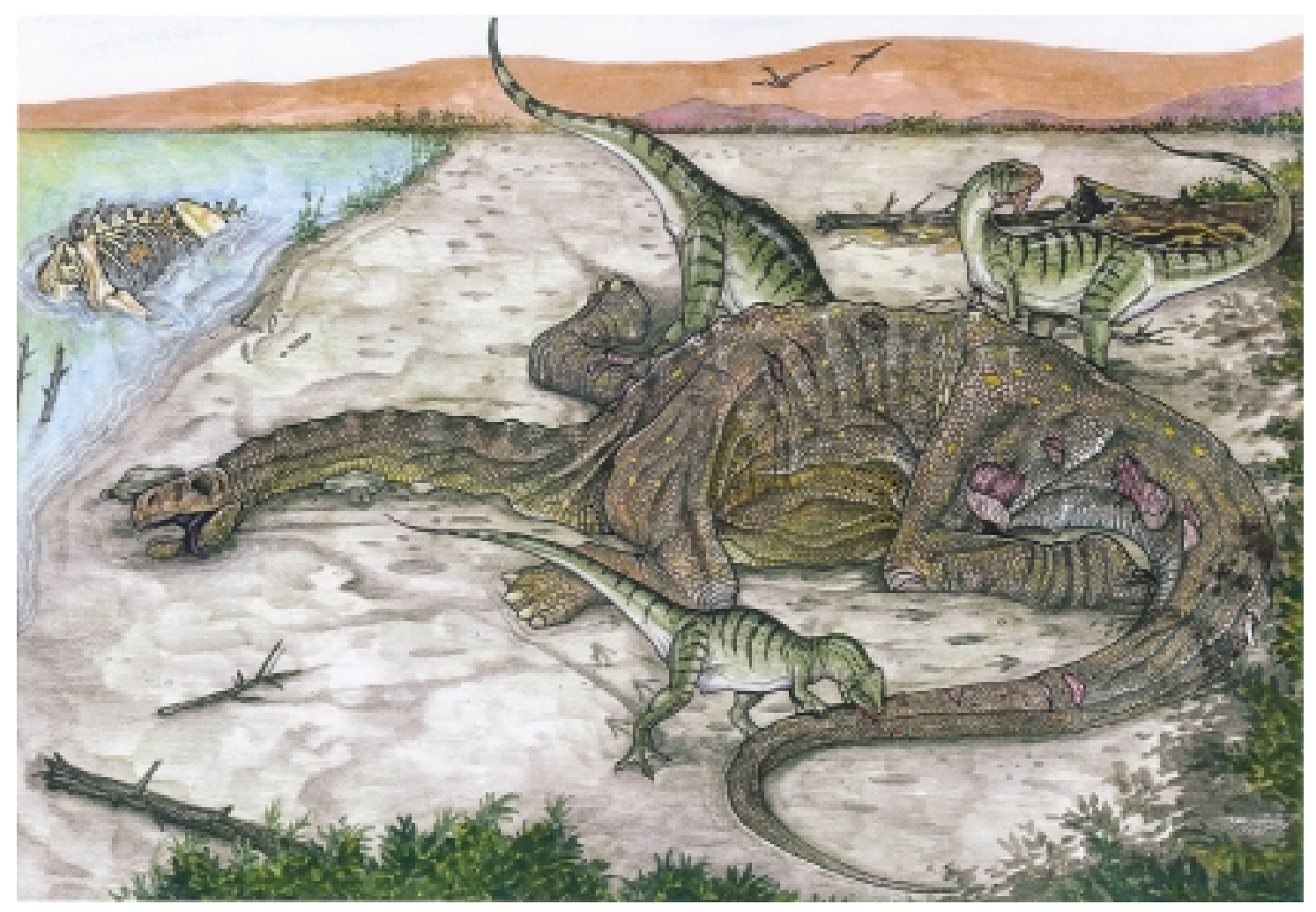

Fig. 22 - Hypothetical scene showing some of the dinosaurian faunal elements that lived in the State of São Paulo during the deposition of the Adamantina Formation (Upper Cretaceous, Bauru Group): the titanosaurid sauropod Gondwanatitan faustoi is scavenged by small abelisaurid-like theropods.

Semiplume (Martill \& Figueira 1994).

Down feather (Kellner et al. 1994, Fig. 17).

Contour feathers with color pattern (Martill \& Frey 1995, Kellner et al. 1999b, this paper Fig. $18)$.

So far the only dinosaur material known from the Crato Member are feathers, first reported by Martins Neto and Kellner (1988). About two dozen of feathers from this unit have been found, but the exact site where they were collected is unknown. In the past, all outcrops of the Crato Member were located around the town of Nova Olinda and were mined for industrial and construction purposes, leading to the suspicion that all published specimens have come from this area. However, with the expansion of the quarrying activities in this region, several new min- ing pits were opened around Santana do Cariri and along the road Nova Olinda - Santana do Cariri. Therefore it is likely that some new specimens might have come from those. In any case, there are several sites where feathers are found around Nova Olinda. No report of tetrapod material is known from outcrops of the Crato Member in other areas of Ceará (e.g., town of Barbalha) or from Pernambuco and Piauí.

\section{Romualdo Member, Santana Formation}

7. Outcrops around Santana do Cariri (Campos \& Kellner 1991).

Theropoda, Spinosauridae

Irritator challengeri Martill et al. 1996 (see also Kellner 1996b) 
Angaturama limai Kellner and Campos 1996

Theropoda, Coelurosauria

Santanaraptor placidus Kellner 1999

Dinosauria indet.

One fragmentary bone (Leonardi \& Borgomanero 1981, Kellner 1996b)

Incomplete sacrum (Frey \& Martill 1995, Kellner 1996b)

8. Vieira locality in Sobradinho, Municipality of Porteiras (Campos 1985)

Theropoda indet.

Incomplete vertebrae (Campos 1985)

Pelvis and other remains (Campos \& Kellner 1991)

Unfortunately, no detailed data is available for the exact dinosaur sites of the Romualdo Member (Santana Formation), which outcrops in several areas in the states of Ceará, Pernambuco, and Piauí. The localities in Piauí remain almost unexplored and very few fossils have been collected there so far. The only site reported in the literature is the Ladeira do Berlenga, where Price (1959) collected the holotype of the crocodilian Araripesuchus gomesii, still the only tetrapod known from this region. A recent exploratory expedition (1999) to this region was carried out by one of the authors (Kellner), revealing that it is limited to one outcrop cut by a road. Abundant fish material was collected there but it is unlikely that any dinosaur specimen (or pterosaurs) known so far comes from this site.

The Pernambuco State shows several outcrops of the Romualdo Member, mainly at mines that quarry gypsum. Some are very rich in fossil fishes and show potential for the findings of tetrapods. However, very limited collecting was done in those areas so far and it is also unlikely that any dinosaur material presently known comes from this region.

Regarding the Ceará State, most outcrops of the Romualdo Member are extensively quarried, either by gypsum mines around Santana do Cariri or by extensive commercial fossil collecting by local people. This activity (which under Brazilian law is illegal) is done primarily around the towns and villages of Santana do Cariri, Porteiras, and Jardim.

Based on the sediments where the dinosaur remains are preserved indicate that there are at least two localities. Specimens like Santanaraptor were found in beige-colored, poorly laminated calcareous nodules, which are very rich in ostracods and fish remains. Those correspond to the "Santana concretions", which are very common around Santana do Cariri (see Maisey 1991: 59). Other dinosaur remains (e.g., pelvis - see Campos \& Kellner 1991) are found in a dark colored matrix rich in organic material, weakly laminated. This kind of concretions is found around the municipality of Porteiras. In any case, no typical "dinosaur bone-bed" is known in any region of the Araripe Basin. Those reptiles are very rare, contrary to other fossil vertebrates like pterosaurs and for all fishes.

\section{Late Cretaceous}

State of Maranhão

\section{Itapecuru Formation (Cenomanian - Santonian)}

9. Itapecuru Mirim River (Ferreira et al. 1994). Theropoda indet

Sauropoda indet

Only teeth form the theropod material, while the sauropod specimen consists of a few incomplete remains, including vertebrae. The latter has been first interpreted as a theropod dinosaur (Ferreira et al. 1994) but closer examination indicates that it belongs to a non-titanosaurid sauropod (Ismar Carvalho, pers. com. 1998).

\section{Cretaceous Strata}

10. Laje do Coringa, Cajual Island, São Marcos Bay.

Isolated sauropod remains (titanosaurid + nontitanosaurid)

Theropod teeth

Spinosaurid teeth

Having a very high potential for new findings, the Laje do Coringa has furnished several isolated 
dinosaur remains, mainly vertebrae and incomplete long bones currently under study (Manuel Alfredo, pers. com. 1998). This is one of the few bone-beds known in Brazil.

11. São Marcos Bay (Price 1947).

Dinosauria indet.

Several isolated dinosaur remains, mostly fragmentary elements and teeth, were collected in several islands in the São Marcos Bay.

\section{State of São Paulo}

\section{Bauru Group}

12. São José do Rio Preto (Ihering 1911, Price 1961).

Titanosauria indet

"Antarctosaurus" brasiliensis Arid and Vizotto 1971

Dinosauria indet

Isolated dinosaur remains (Ihering 1911)

13. Ibirá (Arid \& Vizotto 1963)

Theropod teeth (Arid \& Vizotto 1963).

14. Adamantina (Maciel 1962)

Ribs and femur (Maciel 1962).

15. Adamantina - Pacaembu Paulista (Maciel 1962)

Isolated bones referred to "Titanosaurus" (Maciel 1962)

16. Pacaembu Paulista (Mezzalira 1966)

Sauropod teeth (Mezzalira 1966).

Isolated femur and vertebra (José Martín Suarez, pers. com. 1999).

17. Myzobuchi, Álvares Machado (Cunha et al. 1987)

Gondwanatitan faustoi Kellner and Azevedo 1999

Several dinosaur specimens were found in this area, including an incomplete sauropod skeleton (Cunha et al. 1987), consisting of a new titanosaurid taxon (Kellner \& Azevedo 1999).
18. Guararapes (Leonardi \& Duszczac 1977)

Isolated titanosaurid remains (Leonardi \& Duszczac 1977).

19. Colina (Pacheco 1913)

Isolated femur (Pacheco 1913).

Isolated remains (Roxo 1929, Moraes Rego 1935, Maciel 1962, Martin Suarez 1969).

Some of those isolated remains were attributed to different European dinosaur taxa (e.g., Pacheco 1913, Roxo 1929), what is now considered to be erroneous (Campos \& Kellner 1991). Unfortunately the whereabouts of many of those specimens, particularly the older occurrences, is unknown.

20. Monte Alto (Bertini \& Campos 1987).

Remains of a large titanosaurid sauropod (Bertini \& Campos 1987).

\section{State of Minas Gerais}

\section{Uberaba Formation}

21. Peirópolis

Isolated titanosaurid remains.

Theropod eggs (Campos \& Bertini 1985, Kellner et al. 1998).

\section{Upper portion of the Bauru Group}

22. Monte Alegre de Minas, $50 \mathrm{~km}$ west of Uberlândia (Huene 1931).

Titanosauridae indet.

This small town is located about $50 \mathrm{~km}$ west of Uberlândia (Campos \& Kellner 1999) and according to Huene (1931: 188-189), the sedimentary rocks around the town have furnished several vertebrae and one incomplete femur attributed to titanosaurids.

23. Uberaba (Price 1961)

Several isolated titanosaurid remains.

This town is actually build over fossiliferous rocks of the Bauru Group. Therefore it is quite common that during the construction of roads or wells dinosaur material is found (Campos \& Kellner 1999). 
24. Mangabeira, north of Uberaba (Price 1951). One titanosaurid egg (Price 1951). Isolated remains of titanosaurids (Price 1951).

25. Morro da Galga, close to Uberaba. Isolated titanosaurid remains (Campos \& Kellner 1999) and theropod teeth.

26. Ponte Alta, $35 \mathrm{~km}$ East of Uberaba. Isolated titanosaurid bones (Campos \& Kellner 1999).

27. Locality Cinquentão, $50 \mathrm{~km}$ from Uberaba on the Uberaba-Uberlândia highway.

Isolated titanosaurid bones (Campos \& Kellner 1999).

28. Fazenda Ribeirão, Campina Verde. Isolated Titanosaurid remains (Campos \& Kellner 1999).

29. Road about $45 \mathrm{~km}$ between Campina Verde and Prata.

Titanosaurid remains (Henriques et al. 1998).

30. Serra do Veadinho, Peirópolis (Price 1961).

Titanosauridae (new taxa)

Several isolated and partial articulated sauropod remains (Powell 1987), including two pelves of different titanosaurid taxa (Campos \& Kellner 1999).

Theropoda indet

Theropod teeth (Kellner 1995, 1996b).

Incomplete theropod femur.

Isolated scapula.

The Serra do Veadinho is the richest dinosaur locality found in Brazil so far. Discovered during the construction of a road, this area was extensively quarried from 1947 to 1959 by L. I. Price. Altogether, there are at least five points that have furnished dinosaur material, which are located near to each other. There are at least two different titanosaurid sauropods (Campos \& Kellner 1999) and, based on teeth, several theropod taxa (Kellner 1995, 1996b). Most of those dinosaur remains have not been described so far.

31. Rodovia site, $3.5 \mathrm{~km}$ east from Peirópolis Titanosauridae gen. \& sp. nov.

Several isolated dinosaur remains, including one pelvis that differs from the ones found at the Serra do Veadinho (Campos \& Kellner 1999).

This quarry is also very rich and yielded its first dinosaur fossil in 1969. It was reopened in 1988 by one of the authors (Campos) and the specimen collected there constitute the basis of the dinosaur collection of a museum situated in the town of Peirópolis (Centro de Pesquisas Paleontológicas Llewellyn Ivor Price; see Campos \& Kellner 1999).

\section{State of Mato Grosso}

\section{Cretaceous Strata of Mato Grosso}

32. Fazenda Confusão (Kellner et al. 1995a)

Titanosauridae indet. (Kellner et al. 1995a, b)

The locality Fazenda Confusão is located near the village of Tesouro and is known since 1969, when a local priest found some dinosaur bones on the margins of the Confusão creek, a tributary of the Garças river (Kellner et al. 1995a). There are actually two dinosaur sites along that Creek, which have furnished isolated sauropod bones (Kellner et al. 1995a, b), some of which can be referred to titanosaurids.

\section{Fazenda Roncador}

Theropoda indet.

Incomplete pelvis, tibia, caudal vertebrae, one tooth, and other elements.

Titanosauria indet.

Fragmentary post cranial bones.

The material found at the Fazenda Roncador consists of an incomplete skeleton of a theropod that was found associated with sauropod remains. Based on the vertebrae, the sauropod remains are referable to Titanosauria. 


\section{Morro do Cambambe (Price 1956)}

Theropoda indet.

Sauropoda indet.

The dinosaur record from the Morro do Cambambe are known since 1883 (Price 1961). This unit has been regarded as part of the Bauru Group, but detailed geological work suggested that it belongs to a different lithoestratigraphic unit, which can be correlated to the upper portion of the Bauru Group, the Marília Formation (Ricardo Weska pers com. 1995). Besides some isolated bones, this site has furnished mainly theropod and sauropod teeth (Azevedo et al. 1995).

\section{State of Amazonas}

\section{Sucunduri Formation}

\section{Nova Olinda do Norte (oil well)}

Two theropod teeth (Price 1961).

\section{FINAL REMARKS}

Nowadays the research on dinosaurs is growing around the world. This is also the case in Brazil, but this growth is only perceptible in the last few years. Despite the early interest and start in Brazilian dinosaur research, suggesting a high potential for such fossils in the country, not very much was done in the field until the middle nineties. The result is a very limited number of publications about this subject and only two formally described species (Staurikosaurus pricei Colbert 1970 and "Antarctosaurus" brasiliensis Arid \& Vizotto 1971). In the last five years dinosaur studies in Brazil got some impulse with the discovery of several new taxa, increasing known dinosaur diversity up to eight species (Irritator challengeri Martill et al. 1996, Angaturama limai Kellner \& Campos 1996, Guaibasaurus candelarai Bonaparte et al. 1999, Gondwanatitan faustoi Kellner \& Azevedo 1999, Saturnalia tupiniquim Langer et al. 1999, \& Santanaraptor placidus Kellner 1999). But this is still very little compared to other parts of the world with the same outcrops of Mesozoic (especially Cretaceous) strata.
There are three main problems that can explain this situation. The first one is related to the quality of the Mesozoic outcrops in the country: most areas are extensively covered with vegetation hindering the exposition of fossils. If the region of Minas Gerais and São Paulo where extensive outcrops of the Bauru strata are present would be desertic, they certainly would be extremely productive, comparable to other rich fossiliferous regions, like the Argentinean Patagonia and the Gobi Desert. Nevertheless the results so far showed the existence of some very promising sites that have only been scratched on the surface. With a proper and continuous collecting program one can predict that these areas will unquestionable furnish important specimens (Fig. 23).

The second problem is the reduced number of vertebrate paleontologists in the country. The lack of information about paleontology at all school levels in Brazil limits tremendously the choices for this career option (Kellner 1998).

The third and perhaps main problem that hampers the development of the dinosaur studies in Brazil (as for Vertebrate Paleontology in general) is the lack of financial support for field work. While in several countries like Canada, United States, Germany and Argentina the activities of paleontologists are well supported by governmental and private funding, in Brazil the actual available money for fossil collecting is almost nonexistent. Perhaps with the sole exception is the Centro de Pesquisas Paleontológicas Llewellyn Ivor Price (CPPLIP, in Peirópolis, Minas Gerais) that receives some support from the local government for quarrying a site nearby, there is no other systematic collecting program to our knowledge in the country.

Notwithstanding all those problems, it is clear from what we know about the Brazilian Vertebrate Paleontology that there is a high potential for important specimens (e.g., Kellner \& Campos 1999). This was already demonstrated by the discovery of some extremely well preserved dinosaurs, including the material unearthed from the Romualdo Member of the Araripe Basin with three dimensionally 
preserved bones and associated soft tissue (Kellner 1996a), and several remains collected in the strata of the Bauru Group that compose some of the best preserved dinosaur specimens (particularly sauropods) know so far. Therefore, advances in solving the problems presented above, particularly related to the lack of financial support for field work, can trigger a "Golden Period" for the research of fossil vertebrates in the country as has happened in other parts around the world.

\section{ACKNOWLEDGEMENTS}

We dedicate this paper to our late President Prof. Carlos Chagas Filho for his outstanding contribution to Brazilian Science. We wish to praise the pioneer work of Llewellyn Ivor Price: his persistent field work resulted in the most important and valuable dinosaur collection of Brazil which enable us and others to proceed his work.

We would like to thank the following individuals for making this project possible: Violeta Arraes de Alencar Gervaiseau (URCA, Crato), Plácido Cidade Nuvens (URCA, Crato), Álamo Feitosa Saraiva (URCA, Crato), and José Artur Ferreira Gomes de Andrade (CPCA-DNPM, Crato) for supporting field work at the Chapada do Araripe; Helder de P. Silva (MN/UFRJ) and Juliana M. Sayão (MN/UFRJ) for helping in the field season to the Araripe Basin in 1999; Sergio A. K. Azevedo (MN/UFRJ), Cesar L. Schultz (UFRGS), Átila A. S. Rosa (UFSM), Ruben A. Boelter (UFSM), Luciano A. Leal (UFSM), and Luciana B. Carvalho (USP) for supporting field work in the Late Triassic strata of the Santa Maria and Caturrita formations; José Martín Suarez (UNESP) and Fabio M. Dalla Vecchia (Udine, Italy) for joining the expedition to the Álvarez Machado site in 1998 (São Paulo). Maurílio S. Oliveira (Rio de Janeiro) is thanked for the illustration and Marcelo Trotta (Museu Nacional/UFRJ), Luciana B. de Carvalho (USP, São Paulo), and Deise D. R. Henriques (Museu Nacional/UFRJ, Rio de Janeiro) are thanked for comments on the original version of the ms.
We specially thank Dr. Leny A. Cavalcante (Editor of the Annals of the Brazilian Academy of Sciences, Rio de Janeiro), for the invitation to elaborate this review and for the patience regarding many missed deadlines for submitting this ms. We would also like to thank the $\mathrm{CNPq}$ (Brasília), for the continuous support of our research of fossil vertebrates and FAPERJ (Rio de Janeiro) that partially funded this project (grant n. E-26/150.912/99 to A. Kellner).

\section{REFERENCES}

Allport S. 1860. On the discovery of some fossil remains near Bahia in South America. $Q J$ Geol Soc London, 16: 263-268.

Arcucci AB. 1997. Un nuevo Lagosuchidae (Thecodontia-Pseudosuchia) de la fauna de Los Chañares (Edad Reptil Chaêarense, Triásico medio), La Rioja, Argentina. Ameghiniana, 24(1-2): 89-94.

ARID FM \& VizotTo LD. 1963. Sôbre vertebrados fosseis no município de Ibirá, São Paulo. Ci e Cult, 15(3): 181-182

Arid FM \& VizotTo LD. 1971. Antarctosaurus brasiliensis, um nôvo saurópode do Cretáceo Superior do Sul do Brasil. In: Congresso Brasileiro DE Geologia, 25, São Paulo, 1971. Anais. São Paulo: SBG. p. 297-305.

Azevedo SA, Campos DA, Kellner AWA, Silva VG \& CARvalho LB. 1995. Vertebrados cretáceos do morro do Cambambe, Mato Grosso. In: CoNgresso Brasileiro de Paleontologia, 14., Uberaba, 1995. Atas. Rio de Janeiro: SBP. p. 4-5.

Azevedo SA, da Rosa AA, Boelter RA \& Leal LA. 1998. A prosauropod dinosaur from the Late Triassic of southern Brazil. In: Simpósio Brasileiro DE Paleontologia de Vertebrados, 1., Porto Alegre, 1998. Boletim de Resumos. Porto Alegre: ILEA, p. 14.

BAKKer RT \& GALTOn PM. 1974. Dinosaur monophyly and a new class of vertebrates. Nature, 248: 168172.

Barberena MC, Araújo DC \& Lavina EL. 1985. Late Permian and Triassic tetrapods of Southern Brazil. 
Nat Geo Rés, 1: 5-20.

Berthou P. 1990. Le bassin d'Araripe et les petits bassins intracontinentaux voisins (N.E. du Brésil): formation et evolution dans le cadre de l'ouverture de 1'Atlantique Equatorial. Comparasion avec les bassins ouest-Africains situés dans le même context. In: Simpósio Sobre a Bacia do Araripe e Bacias InTERIORES Do Nordeste, 1., Crato, 1990. Atas.... Crato. p. 113-134.

Bertini RJ. 1996. Evidências de Abelisauridae (Carnosauria: Saurischia) do Neocretáceo da Bacia do Paraná. In: Simpósio Sobre o Cretáceo do BrasiL, 4., Rio Claro, SP, 1996. Boletim. Rio Claro: UNESP. p. 267-271.

Bertini RJ \& CAmpos DA. 1987. Restos de um grande saurópodo em Monte alto, estado de São Paulo. In: Congresso Brasileiro de Paleontologia, 10., Rio de Janeiro, 1987. Resumos das comunicações. Rio de Janeiro: Sociedade Brasileira de Paleontologia. p. 10.

Bonaparte JF. 1982. Faunal replacement in the Triassic of South America. J Vert Paleont, 2: 362-371.

Bonaparte JF. 1995. Origen de los dinosaurios. Anal Acad Nac Cs Ex Fís Mat, 47: 77-88.

Bonaparte JF. 1996. Cretaceous tetrapods of Argentina. Münchner Geowiss. Abh. (A), 30: 73-130.

Bonaparte JF, Franchi MR, Powell JE \& Sepulveda EG. 1984. La formación Los Alamitos (CampanianoMaastrichtiano) del sudeste de Rio Negro, con descripción de Kritosaurus australis n. sp. (Hadrosauridae). Significado paleogeográfico de los vertebrados. Rev Asoc Geol Argentina, 39: 284-299.

Bonaparte JF, Ferigolo J \& Ribeiro AM. 1999. A new early Late Triassic saurischian dinosaur from Rio Grande do Sul State, Brazil. Nat Sci Mus Monogr, Tokyo, 15: 89-109.

BraUn OPG. 1966. Estratigrafia dos sedimentos da parte interior da região Nordeste do Brasil (bacia de Tucano-Jatoba, Mirandiba e Araripe). Boletim do Dept Nac Prod Min, Div Geol Min, 236: 1-69.

Brett-Surman MK. 1979. Phylogeny and palaeobiogeography of hadrosaurian dinosaurs. Nature, 277:
$560-562$.

Campos DA. 1985. Ocorrência de um novo arcossauro na chapada do Araripe. An Acad Bras Ci, Rio de Janeiro, 57(1): 140-141.

Campos DA \& Bertini RJ. 1985. Ovos de dinossauro da formação Uberaba, Cretáceo Superior do estado de Minas Gerais. In: Congresso Brasileiro DE Paleontologia, 9., Fortaleza, 1985. Resumos das comunicações. Fortaleza: SBP. p. 19.

Campos DA \& Kellner AWA. 1991. Dinosaurs of the Santana Formation with comments on other Brazilian occurrences. In: MAISEY JG (Ed.); Santana fossils. Neptune: T.F.H., p. 372-375.

Campos DA \& Kellner AWA. 1999. On some sauropod (Titanosauridae) pelves from the continental Cretaceous of Brazil. Nat Sci Mus Monogr, Tokyo, 15: 143-166.

Carvalho IS, Viana MSS \& Lima Filho MF. 1995. Os icnofósseis de dinossauros da bacia do Araripe (Cretáceo Inferior, Ceará-Brasil). An Acad Bras Ci, 67(4): 433-442.

Casamiquela RM. 1967. Un nuevo dinosaurio ornitisquio Triásico (Pisanosaurus mertii; Ornithopoda) de la Formación Ischigualasto, Argentina. Ameghiniana, 4: 47-64.

Charig A. 1976. Dinosaur monophyly and a new class of vertebrates: a critical review. In: Bellairs AA $\&$ Cox B (Ed.), Morphology and Biology of Reptiles. Linnean Society Symposium 3: 65-104.

Chatterjee S. 1982. Phylogeny and classification of thecodontian reptiles. Nature, 295: 317-320.

Chatterjee S. 1987. A new theropod dinosaur from India with remarks on the Gondwana-Laurasia connection in the Late Triassic. In: McKenzIE GD (Ed.); Gonwana Six: Stratigraphy, Sedimentology and Paleontology. Geophysical Monogr., 42: 183-189.

Chatterjee S \& Creisler BS. 1994. Alwakeria (Theropoda) and Morturneria (Plesiosauria), new names for preoccupied Walkeria Chatterjee 1987 and Turneria Chatterjee and Small 1989. J Vert Paleont, 14: 142.

Chiappe LM. 1995. The first 85 million years of avian 
evolution. Nature, 378: 349-355.

Colbert EH. 1970. A saurischian dinosaur from the Triassic of Brazil. Am Mus Novitates, 2405: 1-39.

Coria RA \& Salgado L. 1995. A new giant carnivorous dinosaur from the Cretaceous of Patagonia. Nature, 277: 224-226.

Coria RA \& Salgado L. 1996. A basal iguanodontian (Ornithischia: Ornithopoda) from the Late Cretaceous of South America. J Vert Paleont, 16(3): 445-457.

Cunha FLS, RÊGo DD \& Capilla R. 1987. Nova ocorrência de répteis cretácicos, no "Sítio Myzobuchi”, da formação Baurú, em Álvares Machado, S.P. In: CoNgresso Brasileiro de Paleontologia, 10., Rio de Janeiro, 1987. Anais. Rio de Janeiro: SBP. v. 1, p. 143-154.

Currie PJ \& Padian K. (Ed.) 1997. Encyclopedia of dinosaurs. San Diego: Academic. 869 p.

Feduccia A. 1996. The origin and evolution of Birds. New Haven and London: Yale University Press. 420p.

Feduccia A \& Wild R. 1993. Birdlike characters in the Triassic archosaur Megalancosaurus. Naturwissenschaften, 80: 564-566.

Ferreira CS, Carvalho IS, Vicalvi MA, Assis JFP, Eugênio WS \& Roberto FF. 1994. Projeto "Paleontologia e Estratigrafia das bacias cretácicas de São Luís e Parnaíba”. An Acad Bras Ci, 66(2): 257.

Frey E \& Martill DM. 1995. A possible oviraptorosaurid theropod from the Santana Formation (Lower Cretaceous, ? Albian) of Brazil. $N \mathrm{Jb}$ Geol Paläont Mh, 1995: 397-412.

Galton PM. 1990. Basal Sauropodomorpha-Prosauropoda. In: Weishampel DB, Dodson P \& OSMOLSKA H. (Ed.); The Dinosauria. Los Angeles: University of Califórnia, p. 320-344.

Gauthier JA. 1986. Saurischian monophyly and the origin of birds. Mem California Acad Sci, 8: 1-55.

Gillette DD \& Lockley MG. (Ed.). 1989. Dinosaur tracks and traces. Cambridge: Cambridge University Press. 454 p.
Gilmore CW. 1922. A new sauropod dinosaur from the Ojo Alamo Formation of New Mexico. Smithsonian Misc Coll, 72: 1-9.

Henriques DDR, Azevedo SA, Kellner AWA, Carvalho LB, Capilla R, Say ão JM, Carvalho AB, Silva HP \& SoARes AA. 1998. New fossils from the Late Cretaceous Group at Prata, Minas Gerais, Brazil. An Acad Bras Ci, Rio de Janeiro, 70(2): 385.

Huene F. 1931. Verschiedene mesozoische Wirbeltierreste aus Südamarika. Neues Jahrb $f$ Min Geol Paläont, Beil-Bd, 66(B): 181-198.

Huene F. 1942. Die fossilen Reptilien des südamerikanischen Gondwanalandes. München, C H. Beck. 332 p.

HuXLEy TH. 1870. Further evidence of the affinity between the dinosaurian reptiles and birds. $Q J$ Geol Soc London, 26: 12-31.

IHERING H. 1911. Fósseis de São José do Rio Preto. Rev Mus Paulista, 8: 141-146.

JI Q, Currie P, Norell M \& JI SA. 1998. Two feathered dinosaurs from northeastern China. Nature, 393: 753-761.

KeLlner AWA. 1994. Remarks on pterosaur taphonomy and paleoecology. Acta Geologica Leopoldensia, 39(1): 175-189.

Kellner AWA. 1995. Theropod teeth from the Late Cretaceous Bauru Group near Peirópolis, Minas Gerais, Brazil. In: Congresso Brasileiro de PaleonTOLOGIA, 14., Uberaba, 1995. Atas. Rio de Janeiro: SBP. p.66-67.

Kellner AWA. 1996a. Fossilized theropod soft tissue. Nature, 379: 32.

Kellner AWA. 1996b. Remarks on Brazilian dinosaurs. Mem Queensl Mus, 39(3): 611-626.

Kellner AWA. 1998. Panorama e perspectiva do estudo de répteis fósseis no Brasil. An Acad Bras Ci, 70(3): 647-676.

Kellner AWA. 1999. Short note on a new dinosaur (Theropoda, Coelurosauria) from the Santana Formation (Romualdo Member, Albian), northeastern Brazil. Boletim do Museu Nacional (Serie Geolo- 
gia), 49: 1-8.

Kellner AWA \& Azevedo SAK. 1999. A new sauropod dinosaur (Titanosauria) from the Late Cretaceous of Brazil. Nat Sci Mus Monogr, 15: 111-142.

Kellner AWA \& Campos DA. 1996. First Early Cretaceous theropod dinosaur from Brazil. $N \mathrm{~J}$ Geol Paläont, Abh, 199(2): 151-166.

Kellner AWA \& Campos DA. 1999. Vertebrate paleontology in Brazil - a review. Episodes, 22(3): 238-251.

Kellner AWA, Martins Neto RG \& Maisey JG. 1991. Undetermined feather. In: MaISEy JG (Ed.); Santana fossils. Neptune: T.F.H., p. 376.

Kellner AWA, Maisey JG \& Campos DA. 1994. Fossil down feather from the Lower Cretaceous of Brazil. Paleontology, 37(3): 489-492.

Kellner AWA, Campos DA, Azevedo SA, Silva VG \& Carvalho LB. 1995a. Vertebrados do Cretáceo Superior de Tesouro, Mato Grosso. In: Congresso Brasileiro de Paleontologia, 14., Uberaba, 1995. Atas. Rio de Janeiro: SBP. p. 68-9.

Kellner AWA, Campos DA, Azevedo SA, Silva VG \& Carvalho LB. 1995b. Dinosaur localities in Cretaceous rocks of Mato Grosso, Brazil. J Vert Paleont, 15(3): 39A.

Kellner AWA, Campos DA, Azevedo SA \& Carvalho LB. 1998. Theropod dinosaur eggs from the continental Upper Cretaceous of Minas Gerais. J Vert Paleont, 18(3): 55A.

Kellner AWA, Azevedo SA, da Rosa AA, Boelter RA \& LEAL LA. 1999a. The occurrence of prosauropod in the terrestrial Late Triassic Santa Maria Formation, Southern Brazil. J Vert Paleont, 19(3): 57A.

Kellner AWA, Schwanke C \& Campos DA. 1999b. O Brasil no tempo dos dinossauros. Rio de Janeiro: Museu Nacional. 60 p.

Langer MC, Abdala F, Richter M \& Benton M. 1999. A sauropodomorph dinosaur from the Upper Triassic (Carnian) of southern Brazil. CR Acad. Sci. Paris, Sci. Terre Planèt, 329: 511-517.

LE Loeuff J. 1991. The Campano-Maastrichtian verte- brate faunas from southern Europe and their relationships with other faunas in the world; paleobiogeographical implications. Cretac. Res., 12: 93-114.

LEONARDI G. 1979. Nota preliminar sobre seis pistas de dinossauros Ornithischia da Bacia do Rio de Peixe, em Sousa, Paraíba, Brasil. An Acad Bras Ci, Rio de Janeiro, 71(3): 501-516.

LEONARDI G. 1984. Le impronte fossili di dinosauri. In: Bonaparte JF et al. (Ed.); Sulle orme dei dinosauri. Venezia: Erizzo, p. 161-186, 27 pl.

Leonardi G. 1994. Annotated atlas of South America tetrapod footprints (Devonian to Holocene) with an appendix on Mexico and Central America. Brasília: CPRM. 247 p.

LeOnardi G \& Borgomanero G. 1981. Sobre uma possível ocorrência de Ornitischia na formação Santana, chapada do Araripe (Ceará). Rev bras Geoci, 11: $1-4$.

Leonardi G \& Duszczac SC. 1977. Ocorrência de Titanosauridae (Sauropoda, Atlantosauridae) na formação Bauru (Cretáceo Superior) em Guararapes, São Paulo. In: Simpósio de Geologia Regional, 1., São Paulo, 1977. Atas. São Paulo. p. 396-403.

MaCiel AC. 1962. Nova ocorrência de vertebrados fósseis em Adamantina - SP. Ci e Cult, São Paulo, 14(3): 167-8, set.

Maisey JG. (Ed.) 1991. Santana fossils: an illustrated atlas. Neptune: T.F.H. 459 p

Martill DM \& Figueira JBM. 1994. A new feather from the Lower Cretaceous of Brazil. Paleontology, 37(3): 483-487.

Martill D \& Frey E. 1995. Colour patterning preserved in Lower Cretaceous birds and insects: the Crato Formation of N.E. Brazil. Neues Jahrb Geol Paläont, Monatshefte 1995(2): 118-128.

Martill DM, Cruickshank ARI, Frey E, Small PG \& Clarke M. 1996. A new crested maniraptoran dinosaur from the Santana Formation (Lower Cretaceous) of Brazil. Jour Geol Soc London 153: 5-8.

Martin Suarez J. 1969. Um quelônio da formação Baurú. In: Congresso Brasileiro de Geologia, 23., Salvador, 1969. Anais. São Paulo: SBG. 
p.167-176.

Martins Neto RG \& Kellner AWA. 1988. Primeiro registro de pena na formação Santana (Cretáceo Inferior), bacia do Araripe, Nordeste do Brasil. An Acad Bras Ci, 60(1): 61-68.

McIntosh J. 1990. Sauropoda. In: Weishampel DB, Dodson P \& Osmolska H. (Ed.) 1990. The Dinosauria. Berkeley: University of California. p. 345-401.

MezzaliRa S. 1966. Os fósseis do estado de São Paulo. Bol Inst. Geogr. Geol., São Paulo, 45: ??

Mikhailov KE, Bray ES \& Hirsch KF. 1996. Parataxonomy of fossil egg remains (Veterovata): principles and application. $J$ Vert Paleont, 16(4): 763-769.

Moraes Rego LF. 1935. Camadas cretaceas do sul do Brasil. Ann Esc Polytech, 4(2): 231-274.

Murry PA \& Long RA. 1989. Geology and paleontology of the Chinle Formation, Petrified Forest National Park and vincinity, Arizona and a discussion of vertebrate fossils of the southwestern Upper Triassic. In: Lucas SG \& Hunt AP (Ed.), Dawn of the Age of Dinosaurs. Albuquerque: New Mexico Museum of Natural History, p. 29-64.

Novas FE. 1993. New information on the systematics and postcranial skeleton of Herrerasaurus ischigualastensis (Theropoda: Herrerasauridae) from the Ischigualasto Formation (Upper Triassic) of Argentina. J Vert Paleont, 13: 400-423.

Novas FE. 1996. Dinosaur monophyly. J Vert Paleont, 16: $723-741$.

Novas FE. 1997. Anatomy of Patagonykus puertai (Theropoda, Avialae, Alvarezsauridae) from the Late Cretaceous of Patagonia. J Vert Paleont, 17(1): 137166.

Pacheco JAA. 1913. Notas sobre a geologia do valle do rio Grande a partir da fóz do rio Pardo até a sua confluencia com o rio Paranahyba. In: Commissão Geographica e Geologica, São Paulo. Exploração do rio Grande e de seus affluentes. p. 33-39, 4 pl.

Padian K. 1997. Phylogeny of dinosaurs. In: CurRIE PJ \& Padian K (Ed.); Encyclopedia of Dinosaurs. San Diego: Academic, p. 546-551.
Padian K \& May CL. 1993. The earliest dinosaurs. New Mexico Museum Nat Hist Sci Bull, 3: 379-381.

Perle A, Chiappe LM, Richen B, Clark JM \& Norell M. 1994. Skeletal morphology of Mononykus olecranus (Theropoda: Avialae) from the Late Cretaceous of Mongolia. Amer Mus Novitates, 3105: 129.

Powell JE. 1987. Morfologia del esqueleto axial de los dinosaurios titanosauridos (Saurischia, Sauropoda) del estado de Minas Gerais, Brasil. In: Congresso Brasileiro de Paleontologia, 10., Rio de Janeiro, 1987. Anais. Rio de Janeiro: SBP. v. 1, p. 155-171.

Price LI. 1947. Sedimentos mesozóicos na baía de São Marcos, estado do Maranhão. Notas prelim. Est. Div. Geol. Mineral., 53: 1-7.

Price LI. 1951. Um ovo de dinossaurio na formação Baurú, do Cretácico do estado de Minas Gerais. Notas prelim Est Div Geol. Mineral., 53: 1-7.

Price LI. 1956. Sôbre a suposta presença de um anomodonte triássico no alto Amazonas. Notas prelim est Div Geol Miner, Rio de Janeiro, 93, 10 p., jul.

PRICE LI. 1959. Sobre um crocodilídeo notosúquio do Cretácico brasileiro. Bol Div. Geol. Mineral, 188: $1-55$.

Price LI. 1961. Sobre os dinossáurios do Brasil. An Acad. Bras. Ci., Rio de Janeiro, 33(3-4): xxviiixxix.

Rogers RR, Swisher III CC, Sereno PC, Monetta AM, Forster CA \& Martínez RN. 1993. The Ischigualasto tetrapod assemblage (Late Triassic, Argentina) and ${ }^{40} \mathrm{Ar} /{ }^{39} \mathrm{Ar}$ dating of dinosaurs origins. Science, 260: 794-797.

Romer AS. 1956. Osteology of the Reptiles. Chicago: University Chicago. $772 \mathrm{p}$

Romer AS. 1971. The Chañares (Argentina) Triassic reptile fauna. X. Two new bu incompletely known long-limbed pseudosuchians. Breviora, 378: 1-10.

Romer AS. 1972. The Chañares (Argentina) Triassic reptile fauna. XV. Further remains of the thecodonts Lagerpeton and Lagosuchus. Breviora, 394: 1-7.

Roxo MGO. 1929. Geologia da região entre rio do Peixe 
e o Paranapanema. Rel anu Dir Div Geol Mineral, 1927: $35-39$.

Salgado L \& Coria RA. 1996. First evidence of an ankylosaur (Dinosauria, Ornitischia) in South America. Ameghiniana, 33(4): 367-371.

Salgado L, Coria RA \& Heredia SE. 1997. New materials of Gasparinisaura cincosaltensis (Ornithischia, Ornithopoda) from the Upper Cretaceous of Argentina. J. Paleont., 71(5): 933-940.

SarJeAnt WAS. 1997. Early discoveries. In: CURRIE PJ \& Padian K (Ed.); Encyclopedia of dinosaurs. San Diego: Academic. p. 340-347.

SEeley HG. 1887. On the classification of the fossil animals commonly named Dinosauria. Proc $R$ Soc London, 43: 165-171.

SeEley HG. 1888. The classification of the Dinosauria. Rep Br Assoc Adv Sci, 1887: 698-699.

SERENO PC. 1991. Basal archosaurs: phylogenetic relationships and functional implications. J Vert Paleont, 11(4): 1-53.

SERENo PC. 1993. The skull and neck of the basal theropod Herrerasaurus ischigualastensis. J Vert Paleont, 13: $151-476$.

Sereno PC. 1999. The evolution of Dinosaurs. Science, 284: $2137-47$.

Sereno PC \& Arcucci AB. 1994. Dinosaurian precursors from the Middle Triassic of Argentina, Marasuchus lilloensis, gen. nov. J Vert Paleont, 14: 5373.

Sereno P \& Novas FE. 1993. The skull and neck of the basal theropod Herrerasaurus ischigualastensis. J Vert Paleont, 13: 451-476.

Silva HP \& Kellner AWA. 1998. Novos dentes de Theropoda do Cretáceo continental do Brasil. In: Simpósio Brasileiro de Paleontologia de VerTebrados, 1., Porto Alegre, 1998. Boletim de Resumos. Porto Alegre: ILEA, p. 21.
Stromer E. 1915. Ergebnisse der Forschungsreisen Prof. E. Stomers in den Wüsten Ägyptens, II. WirbeltiereReste der Baharije-Stufe (unterster Cenoman) 3. Das Original des Theropoden Spinosaurus aegyptiacus nov. gen., nov. spec. Abh. Königl. bayer. Akad. Wiss., 3: 1-32.

Stromer E. 1931. Wirbeltier-Reste der Baharije-Stufe (unterstes Cenoman). 10. Ein Skelett-Rest von Carcharodontosaurus nov. gen. Abh. Königl. bayer. Akad. Wiss., 9: 1-23.

Sues HD. 1990. Staurikosaurus and Herrerasauridae. In: Carpenter K \& Currie PJ (Ed.). Dinosaur systematics: perspectives and approaches. New York: Cambridge University Press, p. 143-147.

Thulborn RA. 1975. Dinosaur polyphyly and the classification of archosaurs and birds. Aust J Zoology, 23: $249-270$.

Thulborn RA. 1982. Speeds and gaits of bipedal dinosaurs. Paleogeogr Palaeoclimatol Palaeoecol, 38: 227-256.

Weishample DB \& WitMer LM. 1990. Lesothosaurus, Pisanosaurus, and Technosaurus. In: WeIsHAMPel DB, Dodson P \& Osmolska H. (Ed.); The Dinosauria. Berkeley: University of California. p. 416-425.

Weishampel DB, Dodson P \& Osmolska H. (Ed.) 1990. The Dinosauria. Berkeley: University of California.

Witmer LM. 1991. Perspectives on avian origins. In: Schulze HP \& Trueb L. (Ed.); Origins of the Higher Groups of Tetrapods. Ithaca: Cronell Univ. Press. p. $427-466$

WoODWARD AS. 1910. On a tooth of Triassic dinosaur from São Paulo, Brazil. Rep $7^{\text {th }}$ Assoc Adv Sci, Winnipeg, 5: 483. 